\title{
The Common Law in the Twentieth Century: Some Unfinished Business
}

\author{
James Gordley $\dagger$
}

TABLE OF CONTENTS

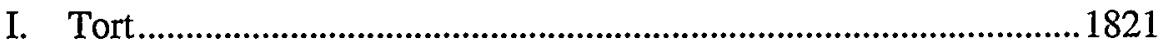

A. CiviI Law and Common Law ............................................1822

B. The Forms of Action and Legally Protected Interests................1827

C. Intent, Negligence and Strict Liability........................................1836

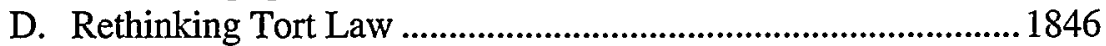

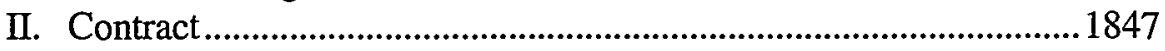

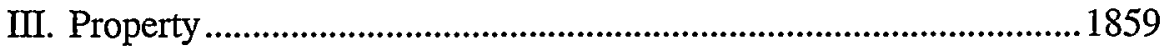

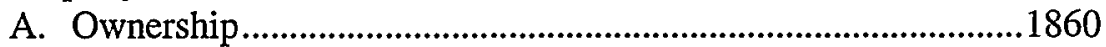

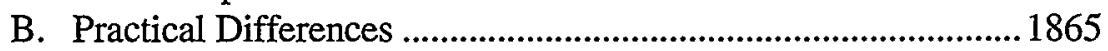

1. Future Interests.....................................................................1865

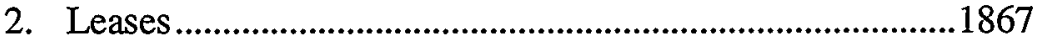

3. Easements and Covenants................................................1868

4. Rethinking the Law of Property ............................................1868

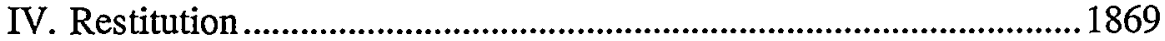

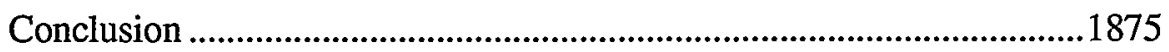

Copyright $\odot 2000$ Califomia Law Review, Inc. California Law Review, Incorporated (CLR) is a Califomia nonprofit corporation. CLR and the authors are solely responsible for the content of their publications.

$\dagger \quad$ Shannon Cecil Turner Professor of Jurisprudence, School of Law, University of California, Berkeley (Boalt Hall). 


\title{
The Common Law in the Twentieth Century: Some Unfinished Business
}

\author{
James Gordley
}

Before the 19th century, the common law was not organized by doctrines or even by areas of law such as contract and tort. It was organized according to forms of action, each with its own rules. In the 19th and 20th centuries, treatise writers rationalized and systematized these rules. Sometimes they borrowed civil law ideas: for example, in tort, they borrowed the distinction between intent, negligence and strict liability; in contract, the doctrines that determine whether agreement has been reached and what damages should be awarded for breach; in restitution, the principle that no one should be enriched at another's expense. Sometimes they responded to civil law ideas: for example, they devised a theory of ownership in response to a civil law debate about possession. Sometimes, they reformulated older common law rules: for example, they equated consideration with bargain and a bargain with a bargained-for-detriment; they redefined the traditional common law actions in what they now called tort. Sometimes, particularly in the law of property and restitution, they simply preserved archaic rules that defied rationalization. The end result, which persisted through the 20th century and which we take to be the common law, is an amalgam of inherited rules, civil law borrowings, and the rationalizations of 19 th and early 20 th century jurists. It is neither traditional nor rational. It is a compromise between the desire of these jurists to be sensible and coherent, and their need to present their work as a mere explanation of the law they inherited. The thesis of this Essay is that to have a coherent private law, we must reject the compromise and weed out the relics of the older common law which these jurists preserved.

By the "common law," we mean two things: law that is based on judicial decisions rather than legislation; and the body of law that originated historically in the decisions of English royal courts. "Common law" in the first sense is judge-made law, but that does not mean that judges lay down rules the way a legislature does. Judges decide the cases before them. Courts and legal scholars are then "bound" by the results that judges have reached, not in the sense that they can never disagree, but in the sense that they try not to do so. Legal analysis begins with the decided cases and 
looks for rules, doctrines, or policies to explain as many of them as possible. The judge that decided the earlier case may have claimed to be following some general rule. Nevertheless, at least in the American understanding, courts and scholars may conclude that a different rule will better explain both the result which that judge reached and the results in similar cases. If so, that rule is a better statement of the law. According to an American proverb, law is made by what judges do, not by what they say.

American jurists claim, with some justification, that this process can often produce better law than legislation.' It is sometimes easier for judges to see that particular results are right than for a legislator to frame a rule or doctrine or to identify a policy that explains why they are right. Thus it often makes sense to arrive at rules, doctrines and policies by examining many particular cases that have already been decided. These rules, doctrines and policies may then influence the decisions in new cases. They may even suggest that certain cases were in fact decided wrongly and should be overruled. When the process works as it should, decided cases reflecting the good sense of judges are the starting point for legal analysis; legal analysis explains the grounds for the decided cases better than the judges who decided them could have done themselves; and this explanation enables judges to decide new cases with a clearer perception of what is ultimately at stake. Conceived in this way, the common law is a process by which the law can become intelligible and rational.

For this process to work, however, the cases must reflect the good sense of the judges who decided them, and what was good sense for them must be good sense for us now. Until the nineteenth century, the judges were not simply asking themselves whether a result was fair or sensible but also whether it should be reached under the forms of action recognized at common law. There was a set number of forms of action corresponding to the types of cases that it was once thought appropriate for the royal courts to hear. The judges bent and stretched these forms of actions to make them fit new cases. Their willingness to do so, however, was not always based on a desire to produce substantively fair results. It was often based on their sense of how far it was appropriate to bend and stretch the recognized forms of action. It was sometimes based on their respect for rules inherited from still earlier times. It was affected by their sense of what issues could be litigated under fact-finding procedures quite different from our own. Our law still contains relics of these decisions. They are often preserved, not because they make sense, but because they are "the common law."

1. See James Gordley, Codification and Legal Scholarship, 31 U.C. DAvIS L. REv. 735 (1998); James Gordley, European Codes and American Restatements: Some Difficulties, 81 Colum. L. Rev. 140 (1981). 
When that is so, the common law in the second sense-a body of law of English origin-is in conflict with the common law in the first sense-a body of law resting on the common sense of judges refined by critical examination.

Indeed, what we often take to be the common law is not in fact the traditional common law. In contract and tort law, it is the result of efforts to rationalize the traditional common law that began with Blackstone, intensified in the late nineteenth century, and, in the United States, culminated in the first series of Restatements. Before Blackstone, the common law was not taught in universities and no one had attempted to organize these decisions systematically into rules or doctrines or to find justifications for them. The common law was not organized by doctrines but by forms of action. The prevalent types of legal literature were the reports and abridgments of decided cases. Blackstone's Commentaries on the Laws of England ${ }^{2}$ was the first attempt to describe the common law systematically. The first treatise on the common law of contracts was written by John Powell in $1790 .^{3}$ The first treatise on the common law of torts was written by Francis Hilliard in $1859 .{ }^{4}$

Despite these developments, judges supposedly still gave relief only in those cases in which the plaintiff would previously have been entitled to it. The treatise writers of the nineteenth and early twentieth centuries claimed that they were merely explaining what the judges had been doing all along. But, as we will see, these treatise writers altered the substantive law itself. By devising explanations for traditional rules, the treatise writers changed the rules themselves. The rules also changed because, in seeking explanations, the treatise writers borrowed a vast amount froin continental law, which already had a systematic doctrinal structure.

There was a limit, however, to how far the search for rational and systematic explanation could go and still claim to be merely an elucidation of the traditional common law. In the early twentieth century, the treatise writers reached that limit in tort and in contract. They could not go further because to do so would have been to emancipate themselves too obviously from the common law as it had been before the effort to rationalize it began.

In reworking the law of property and restitution, the treatise writers stopped even earlier. There were too many particular rules that resisted rationalization. The treatise writers innovated primarily at the level of general principle. In property law, the treatise writers adopted a theory of ownership quite different from that of the continental jurists but fashioned in response to their work. In the law of restitution, they borrowed the civil

2. William Blackstone, Commentaries on the LaWs OF ENGLAND (1765-69).

3. John POWELL, ESSAY UPON THE LAW OF CONTRACTS AND Agreements (1790).

4. Francis Hilliard, The LaW of Torts or Private Wrongs (1859). 
law principle that no one should be enriched at the expense of another. In these fields, however, the rules of English law were simply too strange to be rationalized or reworked on continental lines. Rules survived that did not make sense.

The thesis of this Essay is that our unfinished business, as the century ends, is to complete the task begun by Blackstone and the nineteenthcentury treatise writers: to give a systematic and sensible account of our law. We cannot do so, in my view, without cutting our last ties with the common law in the sense of the law once administered by English royal courts. I do not deny that many of these ties have already snapped. Throughout the century, courts and scholars have innovated interstitially where they saw the need to do so. They have expanded protection in tort by inventing new torts while keeping the old. They have refused to enforce some promises that have consideration and enforced some that do not by expanding the doctrines of unconscionability and reliance and making exceptions to the requirement of consideration. They gave tenants relief from residential leases by borrowing doctrines from contract law while preserving the idea that leases are a conveyance of an interest in land. In the law of restitution, in many jurisdictions, they abandoned strange English rules that limit recovery against a converter who has not sold personal property or a trespasser who has not taken possession of land. One can argueindeed, I have argued ${ }^{5}$ - that the surviving relics of the old common law have been pushed aside when the need to do so was seen clearly.

Nevertheless, these relics inhibit clear thought about law. And while they have been have pushed into corners, they can jump out again to produce indefensible results. Frederick Maitland said, "The forms of action we have buried, but they still rule us from their graves." That is not quite right. What still rules us is not the traditional common law. It is an eclectic jerry-built structure incorporating some traditional English rules, many continental borrowings, the nineteenth- and early twentieth-century academic explanations of both, and a series of ad hoc amendments. It cannot be defended either by an appeal to tradition or to reason. We have this structure because the forms of action were the starting point for the systematizers of the nineteenth century, whose work, in turn, became the starting point for interstitial reform. If we do not wish to be ruled from the grave we will have to bury the forms of action once again, and this time with stakes through their hearts.

5. See James Gordley, Common law und civil law: eine aberholte Unterscheidung, 1993 Zeitschrift für EuropäIsches Privatrecht 498; James Gordley, "Common Law"v. "Civil Law": Una distinzione che va scomparendo?, in 1 SCRITTI IN ONORE DI RODOLFO SACCO: LA

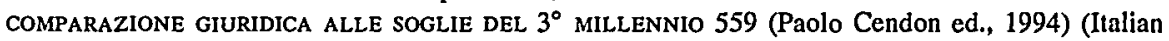
version of Gordley, supra).

6. F.W. Maitland, The Forms of Action at Common Law 2 (1909). 
We will look in turn at the law of tort, contract, property, and restitution.

\section{I \\ TORT}

Maitland underestimated the degree to which, beginning with Blackstone, treatise writers had reworked English law, borrowing from the continent as they did so. In a famous speech, he claimed that while "the history of English law is not yet written," when it is, it will show the evolution, in the forms of action, of "the great elementary conceptions, ownership, possession, contract, tort, and the like." But as Charles Donahue has observed, "we know a considerable amount more today than we did when Maitland wrote. ... Relatively little of the history of the forms of action seems to deal with 'the great elementary conceptions' like

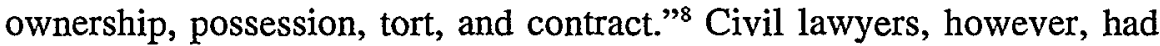
used these categories smce the time of the Roman jurist Gaius. The English and American treatise writers borrowed from them. As Simpson has shown, a series of translations in the early nineteenth century enabled common lawyers to read the work of continental jurists such as Grotius, Pufendorf, Pothier, and Domat in English even if they were unable to do so in their original languages. ${ }^{9}$ Some of the most important concepts the treatise writers imtroduced into the common law were to be found in the works of these authors.

For example, the treatise writers borrowed the concepts of tort and contract as distinct branches of law from continental jurists. The common lawyers had not thought in terms of tort and contract. They thought in terms of actions for trespass in assault and battery, trespass quare clausum fregit (later called trespass to land), trespass de bonis asportatis (later called trespass to chattels), trespass on the case, and so forth. Blackstone said that "personal actions" at common law were either "founded on contracts" or "upon torts or wrongs."10 $\mathrm{He}$ was borrowing a distinction that went back to the Roman jurist Gaius who had distinguished contractus from delictus. ${ }^{11}$ In civil law, this distinction had been recognized as a basic one for centuries.

7. Frederic William Maitland, Why the History of English Law is Not Written, in 1 The Collected Papers of Frederic William Maitland 480, 484 (H.A.L. Fisher ed., 1911).

8. Charles Donahue, JR., Why the History of Canon law is Not Written 6 (1986).

9. See A.W.B. Simpson, Innovation in Nineteenth Century Contract Law, 91 L.Q. REv. 247, 247 (1975).

10. 3 BLACKSTONE, supra note 2 , at $* 117$.

11. See G. INST. 3.88. 


\section{A. Civil Law and Common Law}

Beginning with Blackstone, treatise writers began to remodel what they now called the common law of tort along civilian lines. To see how they did so, we must first take a look at the civil law. By early modern times, continental writers had organized their law of torts around two basic ideas which the common law treatise writers then borrowed. One was the idea that the plaintiff could recover if the defendant harmed him by violating one of his rights or legally protected interests. While this idea seems obvious to us, it had not been explicit in ancient Roman law. Roman law had been a law of particular torts. An action under the lex Aquilia could be brought for physical harm caused by fault. ${ }^{12} \mathrm{~A}$ miscellany of actions lay for physical harm caused without fault. ${ }^{13}$ An action of iniuria could be brought for various types of insulting behavior such as following a woman "assiduously," entering someone's house without permission, injuring someone's reputation, or ridiculing him in various ways. ${ }^{14}$ There were actions with archaic penalties for theft. ${ }^{15}$

By early modern times, continental writers had concluded that, in principle, a plaintiff ought to have an action in tort whenever his rights were violated, and some of them had attempted to list these rights. In the sixteenth and early seventeenth centuries, the most influential of them belonged to a group centered in Spain and known to historians as the "late scholastics" or "Spanish natural law school."16 They tried to understand Roman law in terms of ideas borrowed from their intellectual heroes, Aristotle and Thomas Aquinas. Aristotle had said that a person who harmed another owed him compensation as a matter of commutative justice. ${ }^{17}$ Aquinas enumerated the types of harm for which commutative justice required compensation: harm to one's person itself (as when one is struck, poisoned, or maimed), or to one's dignity (as when one is deprived of one's good name or insulted), or to the personal connections one has with others, or to one's property. ${ }^{18}$ The late scholastics concluded that the Roman distinctions among actions were mere matters of positive law established, doubtless, for some sound reason, but not grounded in principle

12. See generally Reinhard Zimmermann, The Law of Obligations: Roman Foundations of The Civilian Tradition 953-87, 998-1017 (1990).

13. See id. at 1095-1130.

14. See id. at $1050-62$.

15. See id. at $922-943$.

16. On this group, see James Gordley, The Philosophical Origins of Modern Contract DoCTRINe 69-111 (1991) [hereinafter GoRdLey, PHILOSOPHICAL ORIGINS]; James Gordley, Tort Law in the Aristotelian Tradition, in PHILosophical Foundations of TORT LaW 131 (David G. Owen ed., 1995).

17. See Aristotle, Nicomachean Ethics bk. 5, ch. 2, at 1130b, translated in The Basic WORKS OF ARISTOTLE 935 (Richard McKeon ed., 1941).

18. See Thomas Aquinas, Summa Theologiae 1I-II, q. 61, a. 3 (Leonine text, Biblioteca de autores cristianos, $3 d$ ed., 1963). 
or theory. In principle, the plaintiff should recover in tort for any harm to what belonged to him. ${ }^{19}$ Some of them, like Aquinas, tried to list what did belong to a person..$^{20}$ In the seventeenth and eighteenth centuries, these conclusions were accepted and popularized by the members of the northern natural law school founded by Hugo Grotius and Samuel Pufendorf."1 Thus, when the Anglo-American systematizers tried to understand their writs in terms of harm against which the law should give protection, that approach was not a new one.

Modern civil codes have taken this approach. Articles 1382 and 1383 of the French Civil Code impose liability on anyone who intentionally or negligently causes harm to another (dommage). What constitutes legally actionable harm is determined on a case-by-case basis by the courts. Section 823 of the German Civil Code tries to be more precise by enumerating the types of harm that are actionable. The harm must be done to the plaintiff's "life, health, body, freedom [meaning freedom of movement], [or] ownership." The list is not supposed to be exhaustive. According to Section 823 , the defendant is also liable for harm to any "similar right" (sonstiges Recht). What are "similar rights" is decided by German courts on a case-by-case basis. For example, they have held various forms of insult and interference with the defendant's privacy to be actionable. ${ }^{22}$

Obviously, the civil law approach does not answer all the questions one would have about liability in tort. Courts and scholars cannot determine what rights people have by the mere exegesis of terms such as "damage" and "similar right." Nevertheless, the civil law approach does establish a sensible framework for asking and answering questions about the scope of liability. It says that liability depends on whether the plaintiff has been harmed in violation of his rights. Courts and scholars can then discuss what rights should be protected, and whether a right the plaintiff asserts in a new case is like one already protected.

The civil law approach contrasts sharply with the traditional approach of the common law. Traditionally, the plaintiff's right to recover depended not on whether a protected right had been violated, or one similar to a protected right, but instead on whether he could bring his case within one of the recognized forms of action. The forms of action were not a list of protection-worthy interests. They were the end result of centuries of bending

19. See, e.g., LEONARDUS LESSIUS, DE IUSTITIA ET IURE CETERIQUE VIRTUTIBUS CARDINALIS LIBRI QUATUOR lib. 2, cap. 12, dubs. 16, 18; cap 20, dubs. 10-11 (1628); Ludovicus MOLINA, DE IUSTITIA ET IURE TRACTATUS 315, 724 (1614); DOMENICUS SOTO, DE IUSTITA ET IURE LIBRI DECEM 4, q. 6 , a. 5 (1553).

20. See, e.g., Lessius, supra note 19, lib. 2 caps. 3, 9-12.

21. See Hugo Grotius, De IURE belli aC PACIS Libri tres II.xvii.l-2 (B.J.A. de Kanter-van Hettinga Tromp ed. 1939); Samuel Pufendorf, De iURe naturae et Gentium labri octo III.i.3 (1688).

22. See Konrad Ziveigert \& Hein Körz, Einführung IN Die Rechtsvergleichung 693-99 (3d ed. 1996). 
and stretching a fixed number of writs. The number of writs reflected twelfth- and thirteenth-century ideas about what cases the king's courts should hear. If the king's courts did not hear a case, that did not mean that the case was unimportant or that the claimant did not deserve a remedy. $\mathrm{He}$ would simply have to seek it elsewhere: in the baronial courts, the church courts, the merchants' courts, the courts of admiralty, and so forth.

Nevertheless, beginning with Blackstone, common law treatise writers identified the forms of action with different rights or interests which the law was attempting to protect. Blackstone distinguished actions that protected personal property (trespass de bonis asportatis and trover), those that protected real property (trespass quare clausum fregit), and those that protected the "personal security of individuals" against injuries to "their lives, their limbs, their bodies, their health or their reputations. ${ }^{.23}$ Injuries to personal security were redressed by actions for menace and assault in the case of threats, and, in the case of actual injury, by actions of battery for harm to life and limb, actions of malpractice and nuisance for harm to health, and actions of libel and slander for harm to reputation..$^{24}$ As we will see, although the treatise writers of the nimeteenth and early twentieth century proposed different classifications, like Blackstone, they looked for a correspondence between forms of action and interests to be protected.

A second fundamental idea that the treatise writers took from the civil law was that there were three distinct grounds for holding a person liable in tort: he might have harmed someone intentionally, negligently, or by engaging in an activity for which he is strictly liable. In civil law, this distinction has an ancient origin. In Roman law, a plaintiff could recover under the lex Aquilia for harm the defendant caused by culpa, that is, by fault. ${ }^{25}$ In the broad sense, fault includes dolus or intentionally causing harm. ${ }^{26}$ Most often, however, the Romans had in mind primarily what we call negligence, which they illustrated with many concrete examples. A person who cut off the branch of a tree over the public way without calling out was in culpa. ${ }^{27}$ So was someone who burnt stubble on a windy day when his fire might get out of control, ${ }^{28}$ or who shaved a customer near a sports field where a stray ball might strike the hand that held the razor. ${ }^{29}$ If the defendant was not at fault, however, sometimes the plaintiff could still

23. 3 BLACKSTONE, supra note 2 , at *119.

24. See id. at *119-27.

25. See ZimmermanN, supra note 12, at 1007-09.

26. See id. at $1005,1027$.

27. See Dig. 9.2.31 (Paul, Sabinus 10).

28. See Dig. 9.2.30.3 (Paul, Edict 22).

29. See Dig. 9.2.11.pr. (Ulpian, Edict 18). 
recover, though not under the lex Aquilia. ${ }^{30}$ Eventually, the Romans lumped such cases together as "quasi torts" (quasi ex delicto). ${ }^{31}$

This approach is reflected in modern civil codes. As mentioned above, the French and German codes provide that the defendant is liable if he intentionally or negligently harms the plaintiff. The drafters of these codes did not go further and provide for liability absent fault. Yet French courts and German statutes have recognized strict liability. ${ }^{32}$ French courts have held that, even absent fault, a defendant still may be liable in certain situations in which harm is caused by an object in his custody. The German legislature has enacted a series of special statutes which provide for strict liability for the conduct of certain activities such as aviation, railroading, and the generation of electricity. ${ }^{33}$ Thus, again, there are three grounds for liability: intent, negligence, and doing something for which one is liable even absent fault.

Such an approach by itself does not answer all the questions one would have about the limits of tort liability. To determine those limits, one has to think hard about what constitutes intentional or negligent misconduct, and for what types of activities a person should be strictly liable. It is a sensible approach, however, because it indicates that those are the questions that matter, and it invites one to think about them.

The traditional common law did not recognize this three-fold classification of the grounds for liability. A plaintiff could sue in trespass or in trespass on the case. There is a long-standing debate over whether the plaintiff was liable in either action absent fault. As Fifoot and Milsom have pointed out, the question is misleading because, traditionally, the common lawyers did not clearly distinguish fault-based and strict liability. ${ }^{34}$

If the plaintiff sued in trespass, he did not need to allege fault. $\mathrm{He}$ might simply allege, for example, that the defendant shot or struck him. The defendant might then "plead the general issue" by answering with the set phrase, "not guilty." Or, he might make a special plea, in effect, admitting the trespass and offering some justification. There was no clear answer to the question whether either course of action would allow a defendant to escape liability if he were not at fault im the sense in which civil lawyers or modern common lawyers understand fault. If he answered, "not guilty," the jury was supposed to decide whether the plaintiff's allegations were true or false. It is hard to know what juries did. ${ }^{35}$ Presumably, the defendant escaped liability if the jury found that the shooting or striking of the

30. See ZIMMERMANN, supra note 12 , at 1095-1141.

31. See J. INST. 4.5.

32. See ZWEiGERT \& KöTZ, supra note 22 , at 663-71.

33. See id. at 656-63.

34. See C.H.S. Fifoot, History and SOURCES of THE COMmon LAW: TORT AND Contract 189, 191 (1949); S.F.C. Milsom, Historical Foundations of THE COMMON LAW 392-98 (1981).

35. See MiLsom, supra note 34 , at 393. 
defendant was not actually something he did, or that he was the passive instrument of forces of nature, a third party, or the animal he was riding. Possibly, juries decided in the defendant's favor if they concluded he had not committed a trespass or wrong, whatever that might have meant to them. In trespass, the common law did not have a rule when the defendant pleaded the general issue, but merely a procedure: let the jury decide.

If the defendant did not plead "not guilty," he might plead, in justification, that he was not at fault. It was not clear what would happen then. Defendants pleaded that they were not at fault in only a few cases, and the remarks of the judges are confusing and apparently contradictory. Some judges said that the defendant was not liable if he had done his best, ${ }^{36}$ some said that he was, ${ }^{37}$ and some said he could escape liability if his conduct was the product of "unavoidable necessity."38 It is very difficult to know what these statements meant to those who made them. The judges themselves may not have been thinking in terms of a clear distinction between fault-based and strict liability. For example, in Weaver $v$. Ward, ${ }^{39}$ the court said the defendant would be excused if he were "utterly without fault," if the accident were "inevitable," and if he "had committed no negligence to give occasion to the hurt." 40 As Fifoot said of this case, "'[f]ault,' 'inevitable accident,' 'negligence' are words used indiscriminately without reflection and almost without meaning."41

The plaintiff who wished to avoid these uncertainties might sue, not in trespass, but in trespass on the case. The difference was not so much in the substantive law, but that he was then able to allege, not simply that the defendant shot or struck him, but particular circumstances that showed the defendant acted wrongfully. Sometimes, in describing the situation, the

36. See, e.g., The Thorns Case, Y.B. 6 Edw. 4, Mich. fol. 7, pl. 18 (1466) (Choke, C.J.: "As to what has been said that they [thorns] fell ipso invito [on another's land], this is not a good plea; but he should have said that he could not do it in any other manner or that he did all that was in his powcr to keep them out"); Mitten v. Faudrye, Popham 161, 162, 79 Eng. Rep. 1259, 1260 (K.B. 1626) (excusing defendant because he "did his best endeavor"); Wakeman v. Robinson, 1 Bing. 213, 215, 130 Eng. Rep. 86, 87 (P.C. 1823) (Dallas, C.J.: "If the accident happened entirely without default on the part of the defendant or blame imputable to him, the action does not lie....").

37. See, e.g., The Thorns Case, Y.B. 6 Edw. 4, Mich. fol. 7, pl. I8 (1466) (Littlcton, J.: "If a man suffers damage, it is right that he be recompensed."); Bessey v. Olliot, Y.B. 34 Car. 2, Raym. Sir T. 467, 467 (1682) (Sir Thomas Raymond: "In all civil acts the law doth not so much regard the intent of the actor as the loss and damage of the party suffering. ..."); Leame v. Bray, 3 East. 593, 600, 102 Eng. Rep. 724, 727 (K.B. 1803) (Grose, J.: "П]f the injury be done by the act of the party himself at the time or he be the immediate cause of it, though it happen accidentally or by misfortune, yet he is answerable in trespass.").

38. Dickenson v. Watson, Jones, T. 205, 205, 84 Eng. Rep. 1218, 1219 (K.B. 1682) (holding that the defendant who had shot the plaintiff and pleaded accident was not excused "for in trespass the defendant shall not be excused without unavoidable nccessity").

39. Hobart 134, 134, Eng. Rep. 284, 284 (K.B. 1616).

40. Id.

41. Fifoot, supra note 34, at 191. 
plaintiff did allege that the defendant acted negligently. ${ }^{42}$ Even then, it isn't clear what the allegation meant. ${ }^{43}$ It might or might not have meant negligence in the modern (or ancient Roman) sense. Certainly, judges did not instruct the jury to ask whether the defendant had behaved like a reasonable person. In any event, the defendant might also bring an action of trespass on the case without alleging negligence. ${ }^{44}$

Blackstone did not even attempt to read the civil law distinctions among imtent, negligence and strict liability into the common law. As we will see, the treatise writers of the nineteenth and early twentieth century regarded these distinctions as fundamental. ${ }^{45}$ They tried to understand some of the forms of action as intentional torts, and others as based on negligence or strict liability.

These civil law ideas were introduced as part of the process, described above, in which legal doctrines were formulated in an effort to make sense of the case law. In my view, however, that process cannot be carried to completion without eventually snapping the historical links that still bind us to the old forms of action. What courts and scholars have done instead is to stop the process well short of completion. We therefore find ourselves with doctrines that are neither sensible nor traditional.

\section{B. The Forms of Action and Legally Protected Interests}

Hilliard and Addison, in two of the first treatises on tort law, explained that for the plaintiff to recover, he must have suffered some "injury" works, said that he must have suffered some "harm." ${ }^{48}$ Later writers such as Harper and Prosser spoke of the violation of "interests demanding protection" $"$ or "legally recognized interests." Blackstone, tried to identify the traditional forins of action with the

42. See MiLSOM, supra note 34 , at 394.

43. See id. at 399; A.I. Ogus, Vagaries in Liability for the Escape of Fire, 27 CAMBRIDGE L.J. 104, 105-06 (1969).

44. See MiLsom, supra note 34 , at 394.

45. See e.g., John H. Wigmore, Responsibility for Tortious Acts: Its History, 7HaRv. L. REv. 315 (1894).

46. 1 Francis Hilliard, The law of Torts or Private Wrongs 83-84 (2d ed. 1861).

47. 1 C.G. AdDison, WRONGS aNd THEIR Remedies: A TrEatise on the LaW of Torts 2 (4th English ed., F.S.P. Wolferstan ed. 1876).

48. Sir Frederick Pollock, The Law of Torts: A Treatise on the Principles of Obligations Arising from Civil. Wrongs in the Common Law 6 (8th ed., 1908); Sir John Salmond, The LaW of Torts: A Treatise on the ENglish LaW of Liability for Civil INJURies 8 (4th ed. 1916).

49. Fowler Vincent Harper, A Treatise on the Law of Torts: A Preliminary Treatise on Civil Liability for HaRms to Legally Protected Interests 5 (1933).

50. William L. Prosser, Handbook of the LaW of TORTs 8-9 (1941); see also Restatement OF TORTs $\S 1 \mathrm{cmt}$ d (1934) ("legally protected interests"); RESTATEMENT (SECOND) OF TORTS $\$ 1 \mathrm{cmt}$. d (1965) (same). 
protection of distinct types of interests or the prevention of distinct types of harm, damage or injury. At the same time, they tried to formulate a definition or list of the elements that the plaintiff must establish to recover under each of the forms of action.

One difficulty that they faced was that judges traditionally had not decided cases by formulating such lists. They had decided them by looking for resemblances to clear cases in which an action would surely lie. The task of the treatise writers was therefore like that of a British colonial administrator demarcating a boundary line between one tribe claiming the hills and one claiming the lowlands. The fact that he can see clear instances of hills and valleys does not make the boundary between them clear. A further problem was that the cases did not always closely correspond to a distinct interest worthy of protection. When they did, it was easy for the treatise writers to define a particular tort in terms of that interest. For example, false imprisonment could be defined in terms of confinement which deprived the plaintiff of his freedom of movement. Otherwise, unless the treatise writers were to challenge the cases, their choices were limited. They could devise a formula that fit the cases and then invent some reason why it only roughly corresponded to an interest worth protecting. They could recharacterize the interest in question to make it fit their formula more closely. Or, they could ignore the problem.

An example of these difficulties is their search for a definition of battery. The earliest treatise writers said that battery protected a person against bodily harm. Yet bodily harm was not all that mattered, as one can see from their defimitions of battery, which were more like graphic images than boundary lines. Battery is "violence" inflicted on a person" or "an angry, rude, insolent or revengeful touching." 52 Later definitions were less graphic. For example, according to Bigelow and Salmond, battery is an "application of force" to "the person of another" that is "unpermitted"53 or "without lawful justification." 54 But force did not mean harm. Even a person who had not been harmed could recover ${ }^{55}$ Some writers did not try to explain why. Some found a reason why legal protection extended beyond

51. Francis M. Burdick, The LaW of Torts: A Concise Treatise on the Civil Liability at Common law and Under Modern Statutes for actionable Wrongs to Person and PROPERTY 268 (2d ed. 1908); 1 HiLLIARD, supra note 46, at 201.

52. 1 Hilliard, supra note 46, at 201. See also 2 ADDison, supra note 47, at 692 ("the person of a man is actually struck or touched in a violent, rude or insolent manner"); BURDICK, supra note 51, at 268 ("touching of another in anger"); THOMAS M. COOLEY, A TREATISE ON THE LAW OF TORTS OR THE WRONGS WHICH ARISE INDEPENDENT OF CONTRACT 162 (1880) ("injury ... done ... in an angry or revengeful or rude or insolent matter").

53. Melville M. Bigelow, Elements of the LaW of ToRts for the Use of Students 101 (3d ed. 1886).

54. SALMOND, supra note 48 , at 382 .

55. See, e.g., BIGELow, supra note 53, at 101 ("any forcible contact may be sufficient"); SALMOND, supra note 48 , at 382 (force may be "trivial"). 
the interest supposedly in question. The reason, according to Clark, was "the very great importance attached by the law to the interest in physical security." 56 According to Seavy, a "very slight interference is sufficient" because the interest "in bodily integrity" is one of the "most highly protected." ${ }^{\text {"S7 }}$ Salmond redescribed the interest in question: it is "not merely that of freedom from bodily harm, but also that of freedom from such forms of msult as may be due to interference with his person." 58 Harper, Prosser, and the Restatements agreed, ${ }^{59}$ and so were able to redefine battery in a way that fit the cases and also corresponded to the interests that Salmond had identified: the plaintiff could recover for "unpermitted unprivileged contacts with [his] person" touching." $" 1$

Similarly, according to the earlier treatise writers, an action of assault was supposed to protect a "right not to be put in fear of personal harm." Yet, as one can see even from the graphic, image-like descriptions of the earliest treatise writers, this action did not protect against all reasonable fear of harm, or only against fear of harm. They described assault as "an unlawful setting upon one's person"; or "a threat of violence exhibiting the intention to assault, and a present ability to carry the same into execution"; ${ }^{63}$ or an "attempt ... to offer with force and violence to do hurt to another." ${ }^{64}$ Later writers defined assault more tamely as "an attempt, real or apparent, to do hurt to another's person, within reaching distance"; 65 or "an atteinpt with unlawful force to inflict bodily injury upon another, accompanied with the apparent present ability to give effect to the atteinpt if not prevented." ${ }^{16}$ None of them claimed, however, that the plaintiff could always recover or recover only when he had been put in fear. Seavy suggested, as he did in describing the interests protected by battery, that the tort of assault was premised on the importance of personal security, as though that explained the matter ${ }^{67}$ Harper, Prosser and the Restateinents,

56. GeORge L. Clark, The LaW OF 'TorTs 10 (1926).

57. Warren A. Seavey, Principles of Torts, 56 HaRv. L. Rev. 72, 81 (1942).

58. SALMOND, supra note 48 , at 383.

59. See Restatement of TorTs ch. 2, The Interest in Freedom From Harmful Bodily Contact, The 1nterest in Freedom From Offensive Bodily Contact (1934); Restatement (SECOND) OF TORTS ch. 2, The Interest in Freedom From Harmful Bodily Contact, The Interest in Freedom From Offensive Bodily Contact (1965); HARPER, supra note 49, at 38; PROSSER, supra note 50, at 44-45.

60. Prosser, supra note 50, at 43.

61. HARPER, supra note 49, at 39. See also RESTATEMENT OF TORTS \$§ 13, 15, 18-19 (1934); RESTATEMENT (SECOND) OF TORTS $\$ \$ 13,15,18-19$ (1965).

62. COOLEY, supra note 52, at 161; see also BuRDICK, supra note 51, at 266 ("the right to live in society without being put in reasonable fear of unjustifiable personal harm").

63. 1 HiLliard, supra note 46 , at 197.

64. 2 ADDISON, supra note 47 , at 690 .

65. Bigezow, supra note 53 , at 98 .

66. COOLEY, supra note 52 , at 160 .

67. See Seavey, supra note 57, at 73. 
however, redefined the interest at stake as "the interest in freedom from apprehension of a harmful or offensive contact." ${ }^{18}$ That interest corresponded to their more precise definition of assault: it required the "apprehension of a harmful or offensive contact" where apprehension simply meant the awareness that such a contact could imminently occur. ${ }^{69}$

Similarly, the plaintiff's property was supposedly protected by an action for trespass to land, and his reputation by actions for libel and slander. Yet the plaintiff could recover for trespass if the defendant entered his land even if he did no physical damage. He could recover for libel and certain types of slander if the defendant "published" a defamatory statement, whether or not the plaintiff's reputation suffered, or influenced anyone whose opinion mattered to him. This time, none of the treatise writers managed to redescribe the interest at stake to make it conform to the circumstances under which the plaintiff could recover. Some of them found reasons why the law would impose liability when no harm was done. Some said that the law "presumes"70 or "implies"" damage. According to Cooley, it does so in the case of defamation because it would be "unjust" to deprive a plaintiff of recovery who could not prove he had been harmed. ${ }^{72}$ In Salmond's view, "[t]he explanation [is] that certain acts are so likely to result in harm that the law prohibits them absolutely and irrespective of the actual issue." ${ }^{\text {" }}$ According to Seavy, the reason was that, like the interest in bodily integrity, the "interests in reputation, together with those in the possession and ownership of land, are the most highly protected." ${ }^{.74}$ Some writers merely let the matter pass.

The objective of the treatise writers was to make the common law more rational by explaining it in terms of underlying interests. Paradoxically, their efforts in this direction became an obstacle to further efforts. Their explanations made it sound as though somebody - "the law"- - had already decided what interests were worth protecting and how to protect them. Supposedly, for example, the law had decided to protect one's interest in not being offended, but only against offense by physical contact. It had decided to protect one's freedom from the apprehension of imminent harmful or offensive physical contact whether one was put in fear or not. It had decided not only to protect one's interest in land or reputation, but also

68. RESTATEMENT OF TORTS ch. 2, The Interest in Freedom From Apprehension of a Harmful or Offensive Contact (1934); Restatement (SECOND) OF TORTS ch. 2, The Interest in Freedom From Apprehension of a Harmful or Offensive Contact (1965); HARPER, supra note 49, at 43 (same, but speaking of a "harmful or offensive touching"); ProssER, supra note 50, at 48.

69. See Restatement of ToRTs $\$ 21$ (1934); Restatement (SECOND) OF TORTS $\$ 21$ (1965); HARPER, supra note 49, at 43; Prosser, supra note 50, at 48.

70. 1 HilliARD, supra note 46 , at 87 .

71. BuRDICK, supra note 51, at 338.

72. COOLEY, supra note 52 , at 30-31.

73. SALMOND, supra note 48 , at 12 .

74. Seavey, supra note 57 , at 81 . 
to allow recovery even when neither had suffered harm. The treatise writers suggested that the law had made all these decisions without saying that they themselves agreed on the merits.

In fact, such decisions had never been made. Trespass in assault and battery dates from a time when breaches of the peace often led to private vengeance, when the distinction between civil and criminal liability was not yet clear in everyone's mind, and when the very concept of tort as a distinct body of law was centuries off. The rules governing trespass in land were laid down before there were declaratory judgments. As Prosser himself observed, an action in trespass was used, not merely to redress an injury, but to protect "a legal right without which the defendant's conduct, if repeated, might in time ripen into prescription." 75 The rules for defamation were developed at a time when fact-finding was more difficult and the value placed on freedom of speech was quite different. Historically, it would be hard to reconstruct what the common law judges had in mind when they delimited the traditional forms of action. Surely, however, they were not considering what interests each form of action should protect and the best way to protect them.

One unfortunate consequence of the treatise writers' efforts to define and rationalize the common law rules is that we are still taking many propositions as settled which have never been considered on their merits. It is far from obvious that even the least unwelcome physical contact should trigger the plaintiff's right to recover for having been offended; or that absent fear, it is worthwhile to protect the plaintiff from the apprehension of imminent unwelcome contact; or that blanket rules should exempt the plaintiff from having to prove that his land or reputation actually were harmed. The rule exempting the plaintiff from proving damages in defamation was finally changed only by the heavy-handed means of a constitutional decision, and then only partially. ${ }^{76}$

A second unfortunate consequence of the treatise writers' work was that it made a more extensive protection in tort law possible only by confusing the boundaries of old torts or inventing new ones. This process has resulted in doctrinal categories that are neither rational nor traditional. The work of the treatise writers made it painfully clear that tort law protected some interests while neglecting others that are equally important. One way to fill the gaps would have been to change the formulas the treatise writers had devised to make them correspond to interests that should be protected. Instead, gaps were filled by creating new torts alongside the old, and, when that process did not occur fast enough, by fudging and using one of the

75. Prosser, supra note 50 , at 81 .

76. See Gertz v. Robert Welch, Inc., 418 U.S. 323 (1974) (holding that, at least in the case of a media defendant, absent proof of knowledge of falsity or reckless disregard of the truth, plaintiffs must prove that they have actually been harmed). 
traditional torts. As a result, a number of different torts now protect some of the same interests. Some torts now protect a number of different interests. Some of the new torts destroy the limitations imposed by old formulas, and yet the old formulas remain. Thus, the work of the treatise writers has become an obstacle to the very goal these writers pursued: an orderly and systematic description of the common law of tort in terms of the interests that should be protected.

For example, one interest protected by the tort of battery is freedom from bodily harm. But the treatise writers did not define the tort in terms of bodily harm, but in terms of "violence" or "force" or, later, in terms of "touching" or "contact." Salmond, for example, thought that the defendant would not be liable if bodily harm "is inflicted otherwise than by the application of physical force, for example, by administering a deleterious drug." 77 But it would be bizarre to deny people protection against bodily harm simply because it was inflicted without physical contact. In part, the gap has been filled by construing the requirement of contact broadly. Later treatise writers such as Prosser and Harper would say that the drug touched or made contact with the plaintiff. ${ }^{78}$ The gap has also been filled by recogmizing liability for bodily injury caused without physical contact. In the famous English case of Wilkinson $v$. Downton, ${ }^{79}$ a woman suffered physical injury out of anxiety for her husband when the defendants told her, falsely, that he had been injured. As John Fleming has noted, liability in such a case meant that the traditional requirement of physical contact was no longer a barrier to recovery:

[Wilkinson] finally committed our law to the comprehensive proposition that, in the absence of a privilege, all intentional infliction of bodily harm is actionable regardless of the means employed to procure it, be it by direct physical aggression, injurious words or by setting in motion a force which directly or indirectly accomplishes the desired result. ${ }^{80}$

In the first Restatement, this result was accommodated by providing that " $[\mathrm{t}]$ he rules which determine an actor's liability for the infliction of bodily harm otherwise than by harmful bodily contact" are the same as those that determine "liability for the infliction of a harmful bodily contact." In the second Restatement, the result was reclassified as an instance of the new tort of intentional infliction of emotional distress. ${ }^{82}$ Whatever the label, it is hard to see what useful purpose is served by defining battery in terms of contact and then explaining that contact is

77. SALMOND, supra note 48 , at 384 .

78. See HARPER, supra note 49, at 41; PROSSER, supra note 50, at 44.

79. [1897] 2 Q.B. 57.

80. John G. Fleming, The Law OF ToRts 34 (8th ed. 1992).

81. RESTATEMENT OF TORTS $§ 17$ (1934).

82. See Restatement (SECOND) OF TORTs $\$ \$ 17,46$ (1965). 
unnecessary to hold a defendant liable. Indeed, as Fleming points out, with physical injuries, it is hard to see "any point in distinguishing intentional from negligent torts, seeing that ... liability could have been based on fault, embracing both negligent and intentional conduct." $" 83$

According to Harper, Prosser, and the Restatements, another interest protected by the tort of battery is freedom from offensive contact. Protection of that interest is said to explain why the plaintiff traditionally could recover if his body were not harmed but the defendant struck his hat, his walking stick, or the horse he was riding. ${ }^{84}$ Protection of personal dignity against insult, however, is not limited to instances of physical contact. A plaintiff also might be able to recover in defamation. While the treatise writers generally said that this tort protects one's interest in a good reputation, they acknowledged that the plaintiff could sometimes recover absent any allegation of misconduct if he had been insulted or made to look ridiculous ${ }^{85}$ For example, in one famous case, a man who consented to have his picture used in an advertisement recovered for libel because the picture made him look ludicrously deformed ${ }^{86} \mathrm{~A}$ plaintiff whose dignity was offended might also recover for trespass to land, even if the defendant had not harmed his property, provided the defendant had entered it. For example, a gas company was held liable when its meter reader screamed insults at a woman because he made the mistake of putting his hand in her doorway, thereby committing trespass. ${ }^{87}$ A plaintiff may also recover under the new tort of intentional infliction of emotional distress. For example, courts have held defendants liable for cruel practical jokes ${ }^{88}$ or insulting words. ${ }^{89}$

According to the earlier treatise writers, the tort of assault protects against fear of bodily harm; according to the later ones, against the more rarefied mental state of apprehension of imminent harmful or offensive contact with the person. It did not protect one against threats of immediate bodily harm, however credible they might be, provided these threats were made without any menacing gestures. ${ }^{90} \mathrm{It}$ did not protect one against threats to one's property. Nor did it protect one agaimst threats of harm in the future. According to Blackstone, the victim of such a threat could bring

83. FLEMING, supra note 80 , at 34 .

84. See HARPER, supra note 49, at 40-41; Prosser, supra note 50, at 45.

85. See BURDICK, supra note 51, at 302; HARPER, supra note 49, at 499; 1 Hilliard, supra note 46, at 267; ProssER, supra note 50, at 783; SALMOND, supra note 48, at 451.

86. Burton v. Crowell Publ'g Co., 82 F.2d 154 (2d Cir, 1936) (L. Hand, J.). The case the earlier treatise writers cite is Cook v. Ward, 6 Bing. 409 (1830) (finding liability in defamation for a humorous story).

87. See Bouilion v. Laclede Gaslight Co., 129 S.W. 401 (Mo. Ct. App. 1910).

88. See, e.g., Nickerson v. Hodges, 84 So. 37 (La. 1920).

89. See, e.g., Wiggs v. Courshon, 355 F. Supp. 206 (S.D. Fla. 1973).

90. See CLARK, supra note 56, at 15; CoOLEY, supra note 52, at 29; HARPER, supra note 49, at 44; 1 HILlIARD, supra note 46, at 198; PROSSER, supra note 50, at 50; SALMOND, supra note 48, at 383. 
an action for "menace." 91 This possibility was ignored by the treatise writers after Pollock observed that in most of the cases, the plaintiff had recovered for a threat to his servants rather than himself.92 Sometimes, however, the plaintiff who was in fear of harm to his property could bring an action in nuisance to have the cause of the fear removed. Moreover, the victim of a threat of future harm to person or property can now recover under the new tort of intentional infliction of emotional distress. In a famous case, the defendants were held liable for threatening to beat up the plaintiff and wreck his truck. ${ }^{93}$ Again, it is hard to see why it is sensible to have three torts protecting one interest: assault, nuisance, and intentional infliction of emotional distress.

The tort of trespass to land was generally said to protect one's property. As we have seen, however, if the defendant entered plaintiff's land, the plaintiff could recover even if his property had not been harmed. As a result, plaintiff could recover in trespass if the defendant entered plaintiff's premises and violated his privacy, for example, by reading his papers, planting a microphone, eavesdropping, or taking photographs. If the defendant violates the plaintiff's privacy without entering his property, for example, by taking his picture with a telephoto lens or eavesdropping with a parabolic microphone, the plaintiff can now recover for the new tort of "intrusion upon seclusion." 94 Two torts, trespass and intrusion upon seclusion, protect one interest.

The torts of libel and slander were generally said to protect the plaintiff's reputation. Except in the cases of ridicule mentioned earlier, the plaintiff was protected only if the defendant's statements were defamatory: the statement had to lower him in the esteem of the community. $\mathrm{He}$ could not recover if the statements gave him a reputation he did not want or deserve but did not lower him in anyone's esteem. This limitation was overcome in two ways. First, defendants were held liable for alleging, for example, that the plaintiff was insane or had been raped, even though, as Prosser noted, such statements "would be likely to arouse only pity or sympathy in the minds of all decent people." ${ }^{\text {"S5 }}$ Second, plaintiff has been allowed to recover under the new tort of "false light."96 For example, members of a family held hostage by criminals could recover for a false but not defamatory account of their actions. ${ }^{97}$

91. 3 BLACKSTONe, supra note 2 , at $* 120$ (requiring, however, that there be some actual injury such as "through fear . . . a man's business is interrupted").

92. See Frederick Pollock, Principles of Contract 220 (4th ed. 1885).

93. See State Rubbish Collectors Ass'n v. Siliznoff, 240 P.2d 282 (Cal. 1952).

94. Restatement (SECOND) OF TORTS § 652B (1965).

95. PROSSER, supra note 50, at 780.

96. See RestatEMENT (SECOND) OF TORTS § 652E (1965).

97. See Time, Inc. v. Hill, 385 U.S. 374 (1967). 
A further limitation on libel and slander was that the plaintiff could not recover if the defendant's statement was defamatory but true. It has been overcome by allowing the plaintiff to recover for the new tort of "disclosure of embarrassing private facts. ${ }^{.98}$ Yet another limitation was that in certain cases, the plaintiff could not recover in slander without proving special damages, even for words that did obvious harm to reputation. For example, a young girl could not recover when accused of sexual misconduct ${ }^{99}$ or illegitimacy. ${ }^{100}$ To be actionable, such statements had to constitute "slander per se": that is, they had to concern whether the plaimtiff was unfit for a trade or profession, had a loathsome disease, or had committed a serious crime. An allegation of sexual misconduct was actionable without proof of special damages only in states that had imitated England's Slander of Women Act, ${ }^{101}$ and only then, if the plaintiff was a woman. ${ }^{102}$ This limitation has been overcome in cases like those described by allowing the plaintiff to recover anyway, and impounding the cases under the tort of intentional infliction of emotional distress. Thus, four torts protect the interest in reputation: defamation, false light, disclosure of embarrassing private facts, and intentional infliction of emotional distress.

Sometimes the doctrinal category affects whether the plaintiff recovers when his interests are violated. If the plaintiff is insulted, he may find it easier to recover if the defendant nudged him, or committed technical trespass, or ridiculed him in print in a way judged to be defamatory. He may find it more difficult to recover if he must sue for intentional infliction of emotional distress for to reach the jury, he must convince the judge that defendant's conduct was highly offensive to a reasonable person. For similar reasons, he might find it easier to recover for an invasion of privacy accompanied by a technical trespass. If his reputation has been hurt, recovery in defamation will be harder in some ways and easier in others than recovery for disclosure of embarrassing private facts or being placed in a false light. It will be easier because he need not establish the defendant publicized a statement but merely that he "published" it - that is, that he communicated it to any third party. His recovery will be more difficult because he will be subject to special rules that govern such matters, including those of slander per se and privilege. The rules on privilege provide that in certaim cases - for example, when the defendant has an interest in making the statement to a person who has an interest in hearing it-he is liable only if the statement was made maliciously. All of these differences exist simply because we have preserved the definitions of particular torts

98. See Restatement (SECOND) OF TORTS § 652D (1965).

99. See Johnson v. Sampson, 208 N.W. 814 (Minn. 1926) (denying recovery for slander but permitting recovery for injury to health caused by emotional distress).

100. See Walker v. Tucker, 295 S.W. 138 (Ky. 1927).

101. Slander of Women Act, 1891, 54 \& 55 Vict., ch. 51.

102. See Prosser, supra note 50, at 804. 
bequeathed us by the treatise writers. They do not exist because anyone has decided that they should.

Moreover, using this hodgepodge list of particular torts costs us the advantage that a rational doctrinal system would confer: a focus on what ultimately matters. A limitation on recovery established for a particular tort does not matter if it is to be undermined by another. What does matter, as the treatise writers recognized, is the interests we wish to protect. They recogmized that to give a rational account of tort law, we should explain our rules in terms of these interests. That goal is not furthered by a list of torts whose boundaries pay so little regard to which interests are being protected.

\section{Intent, Negligence and Strict Liability}

The second fundamental idea on which the treatise writers rebuilt tort law is that there are three distinct grounds for holding a person liable: he might have harmed someone intentionally, negligently, or by engaging in an activity for which he is strictly liable. Here, a critical change that made the work of the treatise writers possible was the recognition by judges of a separate tort of "negligence" in the late nineteenth and twentieth century. Most treatise writers approved, although it is hard to say whether that is why the judges made the change. A first step was to hold that the plaintiff could not recover for bodily injuries which the defendant caused accidentally and without negligence. In the United States, this step was taken by the Massachusetts Supreme Judicial Court in 1851. As authority, Chief Justice Shaw cited Greenleaf, a law professor at Harvard and author of a treatise on evidence. ${ }^{103}$ In England, this step was not taken until 1891. ${ }^{104}$ In the 1870 s, some courts also held that the defendant would not be liable for trespass to land if he acted neither intentionally nor negligently. ${ }^{105}$ As

103. See Brown v. Kendall, 60 Mass. (6 Cush.) 292 (1850). He also cited Wakeman v. Robinson, 1 Bing. 213 (1823), cited above. See supra notes 36-40.

104. In Stanley v. Powell, 1891 Q.B. 86, the plaintiff claimed that the defendant was negligent, and the jury found that he was not. The court said that the absence of negligence was a defense in an action of trespass, and that the defendant should prevail since the jury verdict established that he was not negligent. In Fowler v. Lanning, 1959 Q.B. 156, the plaintiff merely alleged that "the defendant shot the plaintiff." The court held that the defendant had the burden of proving either intention or negligence. Finally, in Letang v. Cooper, 1965 Q.B. 232, 239 (Eng. C.A.), Lord Denning suggested that the old distinction between actions in trespass and case for direct and indirect injury respectively had been superceded by one between actions in trespass and negligence for intentionally and negligently inflicted harm respectively. If that is so, then English law has finally arrived at the position which American lawyers have long taken for granted. Nevertheless, these last two decisions are still open to revision by a higher court, and English writers are divided as to their merits. Compare W.V.H. ROGERS, WINFIELD AND JOLOWICZ ON TORT 83-84 (15th ed. 1998)(favorable) with R.E.V. HEUSTON \& R.A BUCKLEY, SALMOND AND HEUSTON ON THE LAW OF TORTS 136-37 (21st ed. 1996)(crtical).

105. See River Wear Commissioners v. Adamson, 2 App. Cas. 743, 751 (1877), in which Lord Cairns said that one was liable at common law for "damage occasioned by wilful or negligent misconduct" as distinguished from "act of God," and cases cited by Prosser, supra note 50, at 77-78. 
Prosser pointed out, it would be illogical not to take this step as well: it was "no great triumph of reason" to hold that if a streetcar jumped its track, its operator was liable for injuring a pedestrian only if lie was negligent, but liable for injuring the plate glass window behind the pedestrian whether he was negligent or not. ${ }^{106}$ Yet in his first edition, written in 1941, Prosser could only say that "indications are" that the old rule for trespass to land "is undergoing modification." The indications he cited were the first Restatement of Torts and four cases, three of them decided in the $1870 \mathrm{~s}^{107}$

Meanwhile, the treatise writers were discussing the common law in terms of intent and negligence, or intent, negligence and strict liability. In his early treatise, Addison claimed that the defendant's negligence did not affect his liability. ${ }^{108}$ Hilliard claimed that it did. ${ }^{109}$ In the truly systematic treatises of Salmond and Pollock, the discussion was organized around these grounds for liability. According to Salmond, "[i]n general, though subject to important exceptions, a tort consists in some act done by the defendant whereby he has willfully or negligently caused some form of harm to the plaintiff."110 There must be (a) damage and (b) "wrongful intent or culpable negligence."111 Pollock claimed that in the case of "personal wrongs" such as battery, assault, false imprisonment, slander and libel, liability is imposed where, "generally speaking, the wrong is wilful or wanton. Either the act is intended to do harm, or, being an act evidently likely to cause harm, it is done with reckless indifference to what may befall by reason of it." "12 In contrast, according to Pollock, with respect to the torts of nuisance and negligence, the defendant was generally held liable for "negligence," that is "for a failure to observe due care and caution." 113 Insofar as liability for intent and negligence was concerned, he concluded that "the Roman conception of delict agrees very well with the conception that appears really to underlie the English law of tort."114 To complete the resemblance, English law imposed strict liability for "the ownership and custody of dangerous things," as in Rylands v. Fletcher, where the owner of a reservoir was held liable without fault when the water escaped. ${ }^{115}$ Such liability "has its parallel in Roman law" in liability

106. Prosser, supra note 50, at 77-78.

107. See id. at 78 (citing The Nitro-Glycerine Case, Parrot v. Wells, Fargo \& Co., 82 U.S. (15 Wall.) 524 (1872); Brown v. Collins, 53 N.H. 442 (1873); Losee v. Buchanon, 51 N.Y. 476 (1873); $c f$. Dobrowolski v. Penn. R.R., 178 A. 488 (Pa. 1935)).

108. See 2 AdDison, supra note 47 , at 691 .

109. See 1 HilliaRd, supra note 46, at 83-84, 104-05, 109.

110. SALMOND, supra note 48 , at 8.

111. Id.

112. Pollock, supra note 48 , at 9.

113. Id. at $11,18$.

114. Id. at 17.

115. Id. at 8 . 
"quasi ex delicto."116 Although they characterized the particular torts somewhat differently, Harper, Prosser, and the drafters of the first Restatement, like Pollock, tried to sort them out according to whether the defendant was liable for acting intentionally, for acting negligently, or liable strictly.

But to be held liable, what, precisely, must the defendant intend? As we have just seen, Pollock said the "wrong" must be "wilful" and the defendant is liable if "the act is intended to do harm."117 That was the accepted view in the civil law tradition on which Pollock was drawing; liability for acting intentionally or negligently is liability based upon fault or misconduct. The common law forms of action, however, did not generally require that the defendant intend to do harm or wrong, and they could not be made to do so without considerable retailoring.

Pollock acknowledged that the defendant might be liable for trespass to land or chattels absent an intent to do harm. There was an "absolute duty not to meddle ... with land or goods that belong to others." 118 For a moment, he contemplated discarding this rule as an archaism. He wrote, "[w]e are now independent of the forms of action.... [A] rational exposition of tort law is free to get rid of extraneous matter brought in, as we have shown, by the practical exigency of conditions that no longer exist."119 Nevertheless, he thought that the traditional rule was innocuous enough to retain because it usually gave the right result. He reasoned that "[a] man can but seldom go by pure unwitting misadventure beyond the limits of his own dominion" and that "[i]f not willfully or wantonly injurious, it is done with some want of due circumspection, or else it involves the conscious acceptance of a risk." "120 Thus in all but "exceptional cases," strict liability would not result in "real hardship."121 For Pollock, then, in principle, intent-based liability required an intention to do harm wrongfully. Liability for trespass to land and chattels was not based on intent.

The problem, however, extended beyond trespass to land and chattels. Traditionally, liability for battery, assault, false imprisonment and defamation had not turned on whether the defendant had acted intentionally any more than on whether he had acted negligently. Consequently, the defendant could not escape by proving that he had been mistaken as to the identity of the victim, or the existence of a privilege, or whether a statement was defamatory, any more than he could escape liability for trespass to land by proving he was mistaken as to privilege or ownership. One approach would have been to say, as Pollock did, that since we are now

116. Id. at 18.

117. Id. at 9.

118. Id. at 10.

119. Id. at 15 .

120. Id. at 16.

121. Id. at 11 . 
independent of the forms of action, and since negligence has emerged as an independent tort, we should reexamine whether such a defendant should be liable. Nevertheless, that was not the approach taken by the treatise writers who were Pollock's near contemporaries. They took it for granted, as he did, that if liability were to be based on intent, it was an intent to do harm or wrong that mattered. But they also invented reasons why the law imposed liability where there was no such intent. According to Vold, the defendant was liable for mistakes in identity because "the risk ... should be placed on the intentional wrongdoer rather than his innocent victim." $122 \mathrm{He}$ did not explain why an actor who made a reasonable mistake should count as a wrongdoer. According to Smith, "an intentional entry standing alone and unexplained involves fault." ${ }^{123} \mathrm{He}$ did not ask why the law will not let such a person make an explanation. Salmond thought that the reason was "the evidential difficulties in which the law would find itself involved if it consented to make any inquiry into the honesty and reasonableness of a mistaken belief which a defendant set up as an excuse for his wrongful act." ${ }^{\prime 24} \mathrm{He}$ did not say why the defendant was held liable even if there were no evidential difficulties. These writers thus suggested that the law had already considered and answered a question which, in fact, no one had faced: whether, if liability were to depend on intent, the defendant should be held liable absent an intent to do wrong or harm.

This approach paved the way for the quite different one taken by Seavy, Harper, Prosser and the Restatements. ${ }^{125}$ They took it for granted that the defendant could be liable absent such an intent. But they redefined the intent that matters. It is not an intention to do harm or wrong. According to Seavy, what matters is the intention "to deal with the things or with the interests of others." ${ }^{126} \mathrm{He}$ claimed that "[t]he liability of one whose words unexpectedly prove to be defamatory can be based, in most instances, on his intent to deal with another's reputation." "27 "[M]ost nuisance cases," he said, "involve a realization by the defendant that he is interfering with the factual interests of others." 228 Similarly, Harper claimed that what matters is the intention "to violate a legally protected interest of

122. Lawrence Vold, The Legal Allocation of Risk in Assault, Battery, and Imprisonment-The Prima Facie Case, 17 Neb. L. Bull. 149, 163 (1938).

123. Jeremiah Smith, Tort and Absolute Liability-Suggested Changes in Classification-II, 30

HARV. L. REv. 319, 321 (1917).

124. SALMOND, supra note 48 , at 16 .

125. Beale had yet another explanation. He said that someone who enters land mistakenly thinking it is his own "acts on a mistake as to his authority" and the mistake cannot "give him an authority which in law or in fact he lacks." Joseph H. Beale, Justification for Injury, 41 HARV. L. REv. 553, 559 (1928). He did not explain why one who enters land without authority and without believing that he has authority is liable only if the entry is negligent but one who makes such a mistake is liable without negligence.

126. Seavey, supra note 57 , at 85 .

127. Id. at 85-86.

128. Id. at 86 . 
the plaintiff."129 In the case of trespass to land or chattels the defendant merely needs to intend "the immediate effect of his act which constituted the interference with plaintiff's possession." 130 Therefore, according to Harper, a mistake as to ownership or privilege is no defense. ${ }^{131}$ Harper also explained that, to be liable for defamation, "the defendant must have intended to publish the defamatory matter, that is, he must have voluntarily published the statement which harms the plaintiff's reputation and thus invades his legally protected interests." 132 But he need not have intended that anyone's reputation be harmed. ${ }^{133}$ Like Harper, Prosser said that the intention that matters is not a desire to do harm, but "an intent to bring about a result which will invade the interests of another in a way the law will not sanction." 134 The drafters of the Restatements reached the same conclusions as Harper and Prosser. ${ }^{135}$

Harper claimed that his position rested on a "fundamental principle of policy" which was based on "such deep-rooted notions of fairness and justice that [it] will be found applicable to all legal phenomena in the law of tort." "136 The principle was that "[c]onduct threatens the interests of others in such a manner that it becomes the basis of tort liability only when the actor intends to invade such interests, is negligent toward such interests, or when the conduct is ultra-hazardous with respect to such interests." 137 But by Harper's defimition of intent, one can intend to invade another's interests without intending harm or wrong or even knowing that one is invading the interests of another. Surely there is nothing "deep-rooted" about the idea that such a person should be held liable.

Prosser attempted to explain the rules governing intent in terms of the "the social consequences that will follow." 138 He claimed that if the law were to allow mistake m ownership as a defense to trespass, "the property rights of every owner would be threatened." ${ }^{\prime 39} \mathrm{He}$ also said it is the same

129. HARPER, supra note 49 , at 41 .

130. Id. at 55 .

131. See id.

132. Id. at 504 .

133. See id.

134. PROSSER, supra note 50, at 40-41.

135. See RESTATEMENT OF TORTS $\S 13, \S 13 \mathrm{cmt}$. d, § 158, § $158 \mathrm{cmt}$. e, § 577, § 580 (1934); RESTATEMENT (SECOND) OF TORTS $\S 13, \S 13 \mathrm{cmt}$. c, $\S 158, \S 158 \mathrm{cmt}$. $\mathrm{f}$ (1965). In response to the constitutional challenges to no-fault liability, the second Rcstatement changed its rules to include a requirement of fault for liability in defamation. See RESTATEMENT (SECOND) OF TORTS $§ \S 580,581$.

136. HARPER, supra note 49 , at 6 .

137. Id. He also said that "[1]iability is not imposed unless the actor has conducted his activities in such a manner as to come within one of the foregoing classes." Id. at 12.

138. Prosser, supra note 50, at 9. "So far as they can be rationalized, it must be on the ground that it is acts which are unreasonable or socially harmful, from the point of view of the community as a whole, rather than the sole matter of individually questionable conduct, with which the law of torts is concerned." Id. at 9-10.

139. Id. at 9. 
with an "innocent publisher of words: as against the helpless victim whose reputation is blasted, his act has been regarded, whether rightly or not, as a social menace, and so unreasonable in itself." 140 This explanation is thin. The recognition of negligence as a separate tort means that, in principle, it is not enough that one person has caused harm to another. To be liable for negligence, one must have acted unreasonably. It is hard to see why a person who intends no harm and acts reasonably should be regarded as a threat to property rights or a social menace. Prosser may not have believed his own explanation. ${ }^{141}$

Indeed, after the recognition of a tort of negligence, it is anomalous to hold such a person liable. Suppose a boy taps or kicks another playfully and thereby causes him some serious but unforeseeable injury. Liability for battery depends on whether the incident occurred on the playground, where there might be an "implied license" to engage in such roughhousing, or in the classroom, where there is not. ${ }^{142}$ Suppose the defendant starts a fire in a charcoal burner on the plaintiff's land and a freak wind carries a spark that sets fire to the plaintiff's house. Because he has committed a trespass, he is liable for the harm even if he was not negligent. ${ }^{143}$ But as we have seen, even a reasonable inistake as to whether he was trespassing is not a defense. 1 follows that he would be liable even if he had set up the charcoal burner close to the boundary of his own land. Ultimately, his liability would depend on whether he was correct in thinking he had placed it on his own side of the property line.

Suppose a person smashes another's car. If he did so while driving his own, liability turns on whether he was driving negligently. But as we have seen, mistake in ownership is not a defense. Consequently, if he bought that car from someone who did not have title, then, even though he has every reason to think he owns it, he would be liable no matter how carefully he was driving. Suppose someone writes about the outrageous behavior of a fictitious person with an unlikely name, and by pure chance, someone actually has that naine, and some reader might think the article was about him. Again, the defendant is liable. ${ }^{144}$

The anomaly is still greater when we recognize that courts sometimes hold that a defendant is not liable if he reasonably believed that he was not acting wrongfully. For example, a defendant can escape liability for battery

140. Id.

141. Prosser explained the rules in question only "[s]o far as they can be rationalized." Id. He described the rules as "historical survivals." Id.

142. See Vosburg v. Putney, 50 N.W. 403, 404 (Wis. 1891) (holding that no implied license exists where injuries occur in a school after it has been called into order).

143. See Wyant v. Crause, 86 N.W. 527 (Mich. 1901) (holding adult liable for resulting harm when he trespassed and started a fire in a forge); Brown v. Dellinger, 355 S.W. 742 (Tex. Civ. App. 1962) (holding two children ages seven and eight liable for resulting harm when they trespassed and started a fire in plaintiff's garage).

144. See E. Hulton \& Co. v. Jones, [1910] App. Cas. 20. 
if he had a reasonable belief that he was acting in self-defense even though he was mistaken. ${ }^{145}$ But as we have seen, a reasonable mistake as to identity or privilege does not excuse the defendant. He is excused if he made a reasonable mistake as to whether his conduct would result in an entry on land or harm to another's chattels. For example, he would not be liable if he were driving carefully, and his car went out of control because of a freak patch of ice. ${ }^{146} \mathrm{He}$ is excused in trespass if he made a reasonable mistake as to whether he must tie up his ship at defendant's pier to save his life or property in a storm. ${ }^{147} \mathrm{He}$ is not excused if he is reasonably mistaken as to privilege or ownership. If a third party reads a defamatory statement which the defendant sent the plaintiff, the defendant is not liable if he had no reason to know the letter would be opened by another. ${ }^{148}$ Yet, as we have seen, he is liable if he sent the letter to a third party but had no reason to know the statement was false, or would hurt anyone's reputation.

Nor do the difficulties end there. Although Pollock had said that the defendant must intend "to do harm," he recognized, as continental law also does, that the harm intended need not be precisely the one that occurred. For example, Nym is liable for damage to Pistol's clothes if he strikes Pistol, meaning only to knock him down, but Pistol falls into a ditch where his clothes are spoiled. ${ }^{149}$ Indeed, in dealing with criminal law, Blackstone had said that a person who intended to do wrong is responsible even if he harms a different person than the one he intended to harm. ${ }^{150} \mathrm{~A}$ is responsible if he shoots at $B$ and hits $C$. That principle is unknown to continental civil law, although it has a continental origin. Blackstone had taken it from Hale ${ }^{151}$ and Coke, ${ }^{152}$ who took it from Bracton, ${ }^{153}$ who took it from the thirteenth-century Canon lawyer Raymond of Pennafort, ${ }^{154}$ who had been stating a principle accepted by the Canon lawyers of his own

145. See RESTATEMENT OF TORTS $§ 63(1)$ (a) (1934); RESTATEMENT (SECOND) OF TORTS $§ 63(1)$ (1965).

146. See W. Page Keeton et al., Prosser and Keeton on the LaW of TorTs \$13, at 73-75 (5th ed. 1984).

147. See Vincent v. Lake Erie Transportation Co., 124 N.W. 221 (Minn. 1910).

148. See RESTATEMENT OF TORTS $\$ 577$ (1934); RESTATEMENT (SECOND) OF TORTS $\$ 577(1)$

(1965).

149. See Pollock, supra note 48 , at 33 .

150. 4 BLACKSTONE, supra note 2 , at $* 182-83$.

151. See 1 Matthew Hale, Historia Placitorum Coronae 471-77 (S. Emlyn \& G. Wilson eds., 1800); see also id. at 429-30, 431, 466.

152. See Edward Coke, The Third Part of The Institutes of The Laws of ENGLANd 56-57 (1817).

153. See 2 Bracton, De legibus et consuetudinibus Angliae fol. 120b-121b, at 341 (George E. Woodbine ed. \& Samuel E. Thorne trans., 1968).

154. See S. Raimundus de Pennaforte, Summa de Poenitentia II.i.3 (X. Ochoa \& A. Diez eds., 1976). For his influence on Bracton, see F. Schulz, Bracton on Raymond de Peñafort, 61 L.Q. REv. 286, 289-90 (1945). 
time. ${ }^{155}$ The principle had never passed into continental civil law. ${ }^{156}$ For Blackstone, the principle was irrelevant to tort law since intention did not matter in tort. Nevertheless, some American courts ${ }^{157}$ and scholars ${ }^{158}$ adopted it and applied it to tort cases.

As we have seen, however, according to Harper, Prosser, and the Restatements, the intention that matters is not an intention to do harm or wrong. Therefore one could no longer say that the defendant is liable if he wrongfully intended one harm but did another, or if he wrongfully intended to harm one person but harmed another. According to them, the intention that gives rise to liability is specific to each tort: the intention to make unauthorized contact, to create the apprehension of unauthorized contact, to enter land, to meddle with chattels, or to make a statement. Yet, as we will see, they acknowledged that sometimes a person has been held liable for committing one tort when he intended to commit a different one, or to harm a different person, or sometimes even when he acted intentionally, but his intention did not correspond to any specific tort.

These writers, and the Restatements, addressed this problem by adding three new epicycles to what was already an overly complicated doctrinal system. First, the intention that gave rise to liability for one tort was sometimes defined to include the intention to commit another. For example, the intention requisite for battery was defined to include the one requisite for assault: "the intention of inflicting a harmful or offensive contact ... or of putting the other ... in apprehension thereof." 159 Conversely, the intention necessary to commit an assault was to include the intention necessary to commit a battery. ${ }^{160}$ Indeed, according to Prosser it would be sufficient to have the intention necessary to commit false imprisonment. ${ }^{161}$ The trouble with this solution is that it explained nothing. It simply smuggled a conclusion into a definition.

Second, the intent to commit one tort or to commit it upon one person was said to "transfer" to consequences which, if intended, would constitute

155. See Stephan KuttNer, Kanonistische Schuldlehre: Von Gratian bIS auf die Dekretalen Gregors IX 201-07 (1935); James Gordley, Responsibility in Crime, Tort, and Contract for the Unforeseeable Consequences of an Intentional Wrong: A Once and Future Rule?, in THE LAW of Obligations: Essays in Celebration of John Fleming 175, 184-86 (J. Stapleton \& P. Kane eds., 1998).

156. See Gordley, supra note 155 , at $188-89$. An exception is 1talian criminal law which does recognize the principle. See Codice PENALE art. 82.

157. See, e.g., Talmage v. Smith, 59 N.W. 656 (Mich. 1894); Carnes v. Thompson, 48 S.W. 2d 903 (Mo. 1932); Morrow v. Flores, 225 S.W. 2 d 621 (Tex. App. 1949).

158. See, e.g., Clark, supra note 56, at 4; 1 Hilliard, supra note 4, at 104-05.

159. RESTATEMENT OF TORTS $\$ 18(1)$ (a) (1934); RESTATEMENT (SECOND) OF TORTS $\S 18(1)(a)$ (1965).

160. See RESTATEMENT OF TORTS $\$ 21(1)$ (1934); REstatemENT (SECOND) OF TORTS $§ 21(1)$ (1965); PROSSER, supra note 50, at 52.

161. See Prosser, supra note 50, at 52. 
a different tort or which had been suffered by a different person. ${ }^{162}$ That was supposed to explain cases of the kind just mentioned in which $A$ shoots at B and hits C. As Prosser himself noted, however, to speak of "transferred intent" was "obviously only a fiction." 163 The true reason for holding the defendant liable was that, "[h]aving departed from the social standard of conduct, [he] is liable for the harm which follows from his act although he does not intend it." 164 The doctrine is "an illustration of the general attitude of the courts as to the imposition of greater responsibility on an intentional wrongdoer." ${ }^{165}$ That explanation would work if the doctrine in question were Blackstone's: that one who intends to do harm is liable even if the harm that results is not the one intended. But it does not work when the defendant was not an "intentional wrongdoer" and did not intentionally depart from "the social standard of conduct," even though he had the intention supposedly necessary to trigger liability.

Third, the actor was said to have "intended" consequences which he did not desire as long as he was "substantially certain they would be produced." 166 This principle may have been inspired by criminal law, where the defendant's degree of guilt matters. Why it should apply in tort law as well is far from clear. The cases Prosser cited in support of it in his first edition are not at all on point. ${ }^{167}$ Nevertheless, this principle does make it possible to hold a person liable when the result he intended would not constitute a tort. He is liable provided the consequences, if intended, would do so and he was "substantially certain" that they would occur. The famous case is Garratt v. Dailey, ${ }^{168}$ in which a child who intentionally took an elderly woman's chair without wishing her to hit the ground was held liable for battery because he was "substantially certain" that she would do so. ${ }^{169} \mathrm{It}$ is hard to see why, if the child was old enough to be sure of this consequence, he would not be liable for negligence. In any case, it is hard to see why he should be liable if he is "substantially certain," but not if he is seventy or eighty or ninety percent certain, or slightly less than "substantially certain."

162. See id. at 47; William L. Prosser, Transferred Intent, 45 TEx. L. Rev. 650 (1967).

163. ProssER, supra note 50, at 47.

164. Id. at 48 .

165. Id.

166. Restatement of ToRTS $\$ \S 13 \mathrm{cmt} . \mathrm{d}, 21 \mathrm{cmt} . \mathrm{d}, 35 \mathrm{cmt}$. d (1934); Restatement (SECOND) OF TORTS § 8A cmt. b (1965).

167. See Prosser, supra note 50, at 41. Prosser explained that "[t]he driver who whips up his horscs with a loud yell while passing his neighbor's team will not be credited when he denies that he intended to cause a runaway." Id. (citing Lambet v. Sehreyer, 152 N.W. 645 (Minn. 1915)). Similarly, he said "the defendant on a bicycle who rides down a man in full view on a sidewalk where there is ample room to pass may find the court unwilling to accept his statement that he did not mean to do it." Id. (citing Mercer v. Corbin, 20 N.E. 132 (Ind. 1889)).

168. 279 P.2d 1091 (Wash. 1955).

169. Id. at 1094. 
If the reason for holding him liable is that he should not have appropriated the chair in which someone was about to sit, then one does not need to ask whether he was "substantially certain" of the consequence in order to do so. If the defendant is camping in the arctic and appropriates the plaintiff's sleeping bag after having lost his own, we do not have to ask whether he was substantially certain the other person would freeze to death to hold him liable for that consequence if it occurs. By Blackstone's principle we could simply say that soineone who wrongfully intends to do harm is liable if a different unintended harm occurs. Similarly, by Blackstone's principle, we could hold the boy liable if we were prepared to say it was wrong for hin to take the woman's chair. We could do so whether or not he was substantially certaim she would fall. We could do so without worrying about whether taking a chair in which someone is about to sit is trespass to chattels, which, by the doctrine of transferred intent, would make the child liable for battery.

We do not have to smuggle conclusions into definitions, or to speak of transferred intent or substantial certainty to explain the results just described. I have argued elsewhere that the results can be explained more easily and plausibly by returning to the original principle stated by Blackstone and applied in tort cases by American courts: a person who wrongfully intends to harm another is liable even if the harm that occurs is of a different sort or to a different person. ${ }^{170} \mathrm{~A}$ greedy nephew who kills a man whoin he believes to be his rich uncle is responsible even if the uncle is not rich, but poor. The difference mattered to the nephew, but it should not inatter to the law. Similarly, it should not inatter that the bullet ineant for his uncle happened to strike his aunt.

The approach of the commentators and the Restatements, however, has multiplied the instances in which a person who intended no harm or wrong has been held liable even though he did not act negligently. Suppose a manufacturer's representative tests an insecticide in the plaintiff's husband's store, hoping to persuade him to stock it, and she becomes sick because of a previously unsuspected allergy. Liability in such a case depends not on intent to harm or on negligence, but on whether the plaintiff had implicity revoked the representative's license to test the insecticide in the store. ${ }^{171}$ Suppose the defendant duinps waste water which, unforeseeably, contains contaminants which make his next door neighbor sick. If he is liable for the unforeseen consequences of a trespass he is liable if he wanted the water to enter his neighbor's land, ${ }^{172}$ or, as we have seen, if he was substantially certain it would do so. Suppose, without negligence, the

170. See Gordley, supra note 155, at 186-87, 192-96.

171. See Brabazon v. Joannes Bros. Co., 286 N.W. 21 (Wis. 1939).

172. See Restatement (SECOND) OF TORTS $\$ 158$, cmt. h, illus. 3 (1965) (A is a trespasser if he intentionally throws a pail of water against plaintiff's house). 
defendant accidentally shoots his hunting partner. If we apply the doctrine of transferred intent, he is liable if they happen to have wandered onto the land of a third party even though they believe they are in a national park, unless we say the injured party is in pari delicto because he, too, is a trespasser, in which case the defendant's liability would turn on whether the victim happened to have some implied license to be there which the defendant himself did not. Courts have not gone that far, but that is where these doctrines would logically take them. If these results seem arbitrary, then we need to do something about the doctrines.

\section{Rethinking Tort Law}

Such anomalies are justified neither by an appeal to reason nor to tradition. Courts have preserved them in the naive belief, fostered by the treatise writers, that they are following the common law. But this is certainly not the common law as it was before the treatise writers tried to rationalize it. Traditionally, the forms of action were not supposed to correspond to a set of interests worthy of legal protection. The question of exactly what the defendant must intend to be liable never arose. Liability did not depend on whether the defendant had acted intentionally, or, for that matter, negligently.

Salmond made one of the first systematic attempts to liberate us from the forms of action He said:

In earlier days [the forms of action] filled the law with formalism and fiction, confusion and complexity, and though most of the mischief that they did has been buried with them, some portion of it remains inherent in the law of the present day. Thus if we open a book on the law of torts, howsoever modern and rationalized, we can still hear the echoes of ... old controversies ..., and we are still called upon to observe distinctions and subtleties that have no substance or justification in them, but are nothing more than an evil inheritance from the days when forms of action and of pleading held the legal system in their clutches. ${ }^{173}$

That is true. But, if my argument has been correct, the approach of Salmond and other treatise writers made escape impossible. Salmond asked:

Does the law of torts consist of a fundamental general principle that it is wrongful to cause harm to other persons in the absence of some specific ground of justification or excuse, or does it consist of a number of specific rules prohibiting certain kinds of harmful activity, and leaving all the residue outside the sphere of legal responsibility ${ }^{174}$

173. John W. Salmond, Observations on Trover and Conversion, 21 L.Q. Rev. 43, 43 (1905).

174. SALMOND, supra note 48 , at 9. 
He thought that the second alternative was correct. It is not surprising that he concluded: "even at the present day, all satisfactory definition and classification of the different species of injuries must be based on the old procedural distinctions between forms of action."175 Once that decision had been inade, there was no way to escape the "mischief" he himself had criticized. It would be better to say with Pollock that "[w]e are now independent of the forms of action." 116 Therefore "a rational exposition of tort law is free to get rid of extraneous inatter brought in, as we have shown, by the practical exigency of conditions that no longer exist."177

To solve these problems, we need to scrap our traditional list of torts. We can then consider which interests to protect and when to protect them and so arrive at a coherent list of protected interests. We should also hold the defendant liable for intent or negligence only in cases where he was genuinely at fault: where he either intended an act he knew to be wrongful, or where he failed to use the care of a reasonable person in avoiding harm or in considering whether his act was wrongful. The common law will then look a good deal more like the civil law.

II

Contract

When Anglo-American treatise writers began to systematize the law of contract, as in the case of torts, the raw material was provided by the traditional forms of action. Two forms of action were available to a disappointed promisee: covenant and assumpsit. He could recover in covenant only if the promise had been given under seal, a formality originally performed by making a wax impression on a document. He could recover in assumpsit only if the promise had "consideration."

Whether a promisee recovered in covenant or assumpsit, the law was enforcing a promise. The common law judges had said little about what constituted a promise. The treatise writers therefore were able to borrow again from abroad. Like the civil lawyers, they defined contract in terms of mutual promises or consent to be bound. ${ }^{178}$ They concluded, like the civil lawyers, that contract therefore required an offer and an acceptance. ${ }^{179}$ Eventually, like the civil lawyers, the treatise writers analyzed consent by

175. Id. at 182.

176. PolLOCK, supra note 48 , at 15.

177. Id.

178. See, e.g., Joseph Chitty, A Practical Treatise on the LaW of Contracts 3 (1826); 1 Samuel Comyn, A Treatise of the Law Relative to Contracts and Agreements not Under Seal 2 (1809); 2 James Kent, Commentaries on American LaW 450 (13th ed. 1884); Stephen Martin LeaKe, Elements of the LaW of Contracts 7-8 (1867); William W. Story, A Treatise ON THE LAW OF CONTRACTS NOT UNDER SEAL 1 (1851).

179. See, e.g., SiR William R. Anson, Principles of the English LaW of Contract 13 (1898); KENT, supra note 178, at 477; LEAKE, supra note 178, at 12; STORY, supra note 178 , at 370. 
asking about the effects of mistake, fraud and duress. ${ }^{180}$ A.W.B. Simpson and I have shown that these doctrines were unknown to the earlier common law, and were borrowed, sometimes word-for-word, from continental authors. ${ }^{181}$

Rules to measure damages were also borrowed from abroad. ${ }^{182}$ In Hadley $v$. Baxendale, ${ }^{183}$ the basic rule on the recovery of lost profits was first laid down. It was taken directly from the French jurist Pothier. ${ }^{184}$

One relic from the past is the common law rule that specific performance, the remedy given by a court of equity, can be granted only if the damage remedy available in law was inadequate. In contrast, in some civil law countries such as Germany, the plaintiff is entitled to performance of the promise. ${ }^{185}$ But the difference scarcely matters in practice. If goods are fungible and readily available on the market, it hardly matters whether plaintiff receives the goods or their market value. If goods are not fungible or hard to get on the market, both civil and common law courts will order specific performance. ${ }^{186}$

The most significant survival from the past is the doctrine of consideration. For that reason, my discussion will be concerned entirely with this doctrine. The doctrine of consideration has no parallel in continental law. Traditionally, the requirement of consideration meant that the plaintiff could recover in assumpsit in a variety of disparate cases in which this seemed sensible to judges. Some of these cases were ordinary bargains or exchanges. Some were not, at least not in any ordinary sense: for example, the courts enforced promises to prospective sons-in-law and a variety of gratuitous loans and bailments. ${ }^{187}$

Beginning with Blackstone, Anglo-American treatise writers tried to define and rationalize the consideration requirement. The earlier writers, often citing continental authors, identified "consideration" with what civil

180. See, e.g. , ANSON, supra note 179 , at 158, 156, 203, 218; LEAKE, supra note 178 at 157, 16870, 182; Frederick Pollock, Principles of Contract: Being a Treatise on the General. Principles Concerning the Validity of Agreements in the Law of England 390, 436 (4th ed. 1885); STORY, supra note 178, at 419.

181. See Simpson, supra note 9; GoRDLEY, supra note 16, at 135-46.

182. On the civil law origins of the rule that a contracting party should be placed in the position he would have occupied absent a breach of contract, see James Gordley, Contract and Delict: Toward a Unified Law of Obligations, 1 EdINBURGH L. REv. 345, 346-47 (1997); ZIMMERMANN supra note 12, at $824-25$.

183. 9 Ex. 341, 156 Eng. Rep. 145 (1854).

184. See Robert Pothier, Traité des obligations $\$ 159-60$, in 2 Oeuvres de Pothier (M. Bugnet ed., 2d ed. 1861); ZiMMERMANN, supra note 12, at 830.

185. See, e.g., $\$ 241$ BGB. Section 243 says that he must do so even when the performance is generic goods.

186. See James Gordley, Contract Law in the Aristotelian Tradition, in ESSAYS IN THE THEORY OF Contract LAw 89-90 (Peter Benson, ed.) (forthcoming from Cambridge University Press) (manuscript at 89-90).

187. See A.W.B. Simpson, A History of the Common Law of Contract 416-52 (1975). 
lawyers called the "causa," which means a sensible reason for making a contract. ${ }^{188}$ As Simpson has said, they regarded consideration as a local version of the doctrine of causa. ${ }^{189}$

According to this continental doctrine, there were two causae why a party would make a promise or the law would enforce one: to make a gift or to receive something in exchange. Both are causae, although civil law systems traditionally will not enforce an executory promise of gift unless the promisor completes a formality. As I have shown elsewhere, ${ }^{190}$ from the time it was formulated in the Middle Ages through the eighteenth century, this doctrine meant more than the tautology that a party either did or did not get something for what he gave. Beginning in the Middle Ages, the causa of a gift had been identified with the Aristotelian virtue of liberality, which meant not merely giving wealth but giving it sensibly, to the right people at the right time. The causa of an exchange had been identified with the Aristotelian virtue of commutative justice, which meant not merely that each party received something in return, but that each received something of equivalent value to what he gave. If the value of what he received was disproportionately low, he had a legal remedy. ${ }^{191}$ These ideas can still be found in the writings of the seventeenth- and eighteenth-century natural lawyers, although they often do not mention, and thus may not have recognized, their Aristotelian origin. ${ }^{192}$ The ideas of liberality and commutative justice began to disappear in the nineteenth century when continental lawyers developed "will theories," in which contract was defined in terms of the express will of the parties. There was no room in these theories for concepts of liberality or equality in exchange. ${ }^{193}$

There is a famous and inconclusive debate about whether English judges had the continental doctrine of causa in mind when they required consideration in an action of assumpsit. In any event, they rapidly gave consideration a different meaning. In civil law, the causa of a promise could be to make a gift and not merely to exchange. In common law, a promise to make a gift ordinarily did not have consideration. Moreover, the common law judges found consideration in a variety of promises that were

188. See 2 BLACKSTONE, supra note 2 , at *442; COMYN, supra note 178 , at $8 ; 1 \mathrm{KENT}$, supra note 178, at 630; 1 John J. Powell, EsSAy UPON THE LAW OF CONTRACTS AND AGREEMENTS 331 (1790); Story, supra note 178 , at 431 \& n. 1; William Taylor, A TREatise on the Differences BetweEN THE LAws of ENGLAND ANd Scotl,and Rel,ating to Contracts 16 (1849).

189. See Simpson, supra note 9, at 262.

190. See GoRdLEY, PhILosophical ORIGINS, supra note 16 at 49-57, 77-79.

191. See id. at 77-79.

192. See, e.g., Jean Domat, Les Loix Civiles Dans Leur ORdre Naturel bk. 1 , tit. $1, \S 1$, Nos. 5-6; $\$ 5$, No. 13; Pothier, supra note 184, $\$ 42$. Similarly, Grotius and Pufendorf classifed contracts into two general categories depending on whether they were gratuitous or whether the plaintiff was seeking something in return. See Grotuus, supra note 21, II.xii.1-7; PufENDORF, supra note 21 , at V.ii.8-10.

193. See GordLey, PhilosophiCal Origins, supra note 16 , at 164-71. 
not exchanges in any ordinary sense, such as gratuitous loans and bailments and promises to prospective sons-in-law. Indeed, it is misleading to compare the two doctrines because they were developed for quite different purposes: the continental doctrine was developed to identify two reasons why, in principle, a promise should be made or enforced, while the common law doctrine of consideration was developed as a pragmatic tool for limiting the enforceability of promises. Consideration was not a concept that one could define.

By identifying consideration with exchange, the treatise writers gave the common law a shape like that of the civil law. In civil law, the traditional causae were liberality and exchange. Gifts of money or property traditionally had required a formality called insinuatio which was eventually replaced, in modern civil law, by that of appearing before a notary to subscribe to a document containing the promise. ${ }^{194}$ Contracts of exchange did not. If consideration meant bargain, then the two common law forms of action were similar. Gratuitous promises were enforceable in covenant only if the promisor observed the formality of giving the promise under seal. Contracts of exchange had consideration and therefore were enforceable in assumpsit without any formality at all.

Once the treatise writers had equated consideration with exchange, two problems arose for them. One problem was that courts had found consideration for promises that were not given as part of an exchange. The second problem was that the way continental writers traditionally had defined exchange was no longer acceptable in the nineteenth century. Traditionally, continental writers had said that the causa or purpose of each party in an exchange was to obtain an equivalent for what he gave. Some nineteenth-century treatise writers continued to speak of the purpose or motive of parties, and even of an equivalence in value. Langdell, for example, said that "[a]s every consideration is in theory equal to the promise in value, so it is in theory the promisor's sole inducement to make the promise." ${ }^{\prime 195}$ Such ideas seemed plausible when the Aristotelian philosophy was still in fashion: Aristotle had said that a person acts for an immediate end, or causa finalis, and that commutative justice requires equality in exchange. ${ }^{196}$ By the nineteenth century, however, these ideas were becoming unintelligible. Holmes pointed out that "[a] man may promise to paint a picture for five hundred dollars, while his chief motive may be a desire for fame." 197 Pollock began his discussion of consideration by quoting Hobbes: "The value of all things contracted for is measured by the

194. See ZimmermanN, supra note 12 , at 491-93, 498-504.

195. Christopher Columbus Langdell, A Summary of the Law of Contracts 78-79 (2d ed. 1880).

196. See GoRdLey, Philosophical ORigins, supra note 16, at 13, 17-18.

197. O.W. Holmes, JR., The COMmon Law 293 (1881). 
appetite of the contractors, and therefore the just value is that which they be contented to give." 198

Pollock found an ingenious solution to these problems. He said that "whatever a man chooses to bargain for must be conclusively taken to be of some value to him." ${ }^{199}$ This was so even if he received nothing, consideration having passed to a third party. "[B]y a deduction from this [principle]," Pollock arrived at the common law rule that a court will not "enter into an inquiry as to the adequacy of the consideration."200 To say that the parties had entered into a bargain or exchange therefore meant simply that the promisor was induced to give his promise by some change in the position of the promisee. ${ }^{201}$

Although the language just quoted is from later editions of Pollock's treatise on contracts, the core of his theory of consideration was presented in the first edition, pubhished in $1876 .{ }^{202}$ Pollock had sent the manuscript to his friend, Oliver Wendell Holmes, who adopted a theory much like it. ${ }^{203}$ Williston followed Holmes ${ }^{204}$ and the theory passed into the first Restatement of Contracts ${ }^{205}$ and, eventually, into the Second Restatement. ${ }^{206}$ It became known as the "bargamed-for detriment" theory of consideration, and has been taught to generations of American law students. One reason for its popularity, at least initially, was that it could transmute transactions into bargains as long as one of the promisor's motives was to get something from the promisee. Supposedly, the promise to the prospective son-in-law had consideration because it was made, in part, to induce him to marry. The promise of the gratuitous bailee to look after the object he received had consideration, in part, because it was made to induce the lender to part with it.

The end result in contract law was like the one we have seen in tort. In an attempt to make the law more rational, a traditional requirement was reinterpreted. As reinterpreted, it was regarded by courts and scholars as

198. PoLLOCK, supra note 180, at 173.

199. Id. at 172 .

200. Id.

201. See id. at 164.

202. See id. at 150-51 (1st ed. 1876) ("[T]he leading and characteristic point of the modern learning of Consideration [is] that when a thing is done at a man's request the law does not ask whether it is for his apparent benefit, but takes it as against him to be of the value he has himself chosen to put upon it.").

203. Pollock sent him a copy of the manuscript of the first edition; Holmes wrote back that the account of consideration "was the best which I had seen." Letter from Pollock to Holmes, Dec. 16, 1875, in 1 Holmes-Pollock LetTers 276 (M. Howe ed., 2d ed. 1961); Letter from Holmes to Pollock, June 17,1880 , in id. at 14, 15. Holmes then published his own theory of consideration. See Holmes, supra note 197, at 293-94.

204. Samuel Williston, Consideration in Bilateral Contracts, 27 HARv. L. REv. 503, 516-18

(1914).

205. See RESTATEMENT OF CoNTRACTS $\$ 75$ (1932).

206. See RESTATEMENT (SECOND) OF CONTRACTS $\$ 71(1)$ (1979). 
part of the common law. Further change, supposedly, would entail changing or reforming the law. Therefore, a non-traditional formulation intended to rationalize the law became a barrier to further rationalization.

The doctrine became a barrier to further rationalization because it applied a single concept-consideration, or bargained-for detriment-to cases in which the reasons for enforcing or not enforcing a promise are quite different. One of Corbin's key insights was that the doctrine of consideration is many-faceted and cannot be reduced to a single concept. ${ }^{207}$ In my view, the problems inherent in applying a single doctrine to such a variety of legal problems are incurable. Consequently, the doctrine should be dismantled. I do not propose that we simply abolish it. I think we can learn froin it. But to do so, we have to distinguish the different purposes that are served by the doctrine of consideration and formulate different rules that better serve each of these purposes. Elsewhere, I have discussed how I would think that task can best be performed. ${ }^{208}$ Here, I will merely try to show that any progress in that direction cannot leave the doctrine of consideration intact.

One purpose of the doctrine of consideration, surely, is to discourage a would-be donor from acting rashly. In that respect, the doctrine is like the civil law rule that promises of gifts are not enforceable without a formality, such as subscribing to the promise in front of a notary, who in Europe is a member of the legal profession and quite different from an American notary public. Indeed, the practical effect of the doctrine of consideration is inuch the same. The would-be donor can make a binding commitment. In a few jurisdictions, he can still use a seal to do so. ${ }^{209}$ Otherwise, he can use a trust, for example, naming himself as trustee, and providing that he himself, as a beneficiary of the trust, will have the use of the object until a certain date, when it will be turned over to the donee. ${ }^{210}$ The trust can be made irrevocable; indeed it will be presumed irrevocable, unless he states otherwise. ${ }^{211}$ In practice, few lay people are likely to know how to make a deed under seal or establish a trust. Thus the effect of the doctrine of consideration is much the same as that of the civil law requirement of a formality: one cannot make a gift without consulting a nember of the legal profession. The doctrine thus encourages one to think before acting.

A second function of the doctrine is to make gratuitous loans and bailments enforceable, but only upon delivery. If $A$ promises gratuitously to loan $B$ his car so $B$ can use it, the promise is not enforceable because $B$

207. See 1 ARTHUR Linton Corbin, Corbin on Contracts $\S 109$ (1963).

208. See James Gordley, Enforcing Promises, 83 CALIF. L. REv. 547 (1995).

209. In about one-third of the states, there are no statutory provisions limiting the effect of the seal. See Restatement (SECOND) OF ConTracts stat, note to ch. 4, topic 3 (1979).

210. See 1A Austin WaKeman Scott \& William Franklin Fratcher, The LaW of Trusts § 57.6, at 188 (4th ed. 1987).

211. See id. $\$ 29$, at 315 . 
has promised nothing in return. If $A$ delivers his car to $B, B$ 's promise to look after it is enforceable because $B$ has received the use of the car. ${ }^{212}$ It might seem impossible to find consideration if $B$ is supposed to look after $A$ 's car for him but is not to use it himself. In such a case, the transaction would be entirely for the benefit of $A$. Nevertheless, in the famous English case of Coggs v. Bernard, ${ }^{213}$ the court held that there was consideration for the promise of a person who had agreed to carry a cask of brandy gratuitously. Delivery of the cask was said to be consideration. ${ }^{214}$ Later, when the bargained-for detriment theory was invented, it was hard to explain how that could be since the delivery was not an inducement for the promise. ${ }^{215}$ Nevertheless, the rule remains.

Although the doctrine of consideration has no civil law parallel, its practical effect in transactions like these is much like Roman law. In Roman law, if a thing such as a car is loaned for the use of the borrower, the transaction is called commodatum, it is a mutuum if fungibles such as grain or money are loaned for his use, and a depositum if goods are entrusted to someone who is to look after them but not to use them. These types of contracts are all gratuitous. In Roman law, they become binding only when the object in question is delivered. ${ }^{216}$

Most modern civil law systems have changed this rule. Promises to enter into such transactions are enforceable in advance of delivery. ${ }^{217}$ It is not obvious, however, whether the solution in civil law systems or the solution in Roman law and common law is better. On the one hand, these transactions are gratuitous. If promises of gifts are not enforceable in advance because of the need for deliberation, perhaps they should be unenforceable before delivery as well. On the other hand, a gift benefits the donee at the donor's expense. In the transactions just described, the benefit might be conferred without cost: the person who lends the car for another's use may not need it himself, and the person who agrees to store but not use another's car may have extra space in his garage. If so, there is no cost to the commitment and so no danger that it will be made rashly.

Common law judges have never considered whether such promises should be enforceable because they may be costless, or whether they should not be enforceable because, like gifts, they are gratuitous. A unitary doctrine of consideration does not permit them to do so. The doctrine of consideration does a double disservice: it prevents judges from

\footnotetext{
212. See Restatement (SECOND) OF CONTRACTs $\$ 71$, cmt. c., illus. 8 (1979).

213. 92 Eng. Rep. 107 (K.B. 1703).

214. Id. at 114 .

215. See PoLlock, supra note 180 , at 174 n.(n).

216. On these contracts, see ZimmERMANN, supra note 12, at 153-229.

217. For a study of the extent to which this rule has been changed, see JAMES GORDLEY, THE Enforceability of Promises in European LAw cases 5 \& 7 (forthcoming, Cambridge University Press).
} 
considering the merits of enforcing costless promises while creating the illusion that the merits have already been considered.

A third function of the doctrine is to make unfair promises unenforceable. A situation in which one party has demanded better terms than those that were imitially agreed upon is one example of an unfair promise. It is now generally recognized that the doctrine of consideration is too blunt an instrument to deal with this situation. Sometimes a modification can be fair, for example, because circumstances have changed unexpectedly or because the parties contracted with the expectation that they would make periodic adjustments in the amount of compensation, even though the contract does not expressly provide for them. The doctrine of consideration does not enable a court to discriminate between fair and unfair modifications. Consequently, both the Uniform Commercial Code (U.C.C.) and the second Restatement dispense with the doctrine. According to the U.C.C., modifications of a contract do not need consideration provided that they are made in "good faith." 218 According to the second Restatement, they do not need consideration provided that they are fair because circumstances have changed, or the promisee has changed his position in reliance on the modification. ${ }^{219}$ Thus, it has become possible to consider which promises are so unfair that they should not be enforced, but only by abandoning the doctrine of consideration.

Another type of promise that may be unfair is one in which the promisee is not committed. As in the previous example, the trouble is that not all such promises are unfair. They are only unfair if they merely allow one party to speculate at the other's expense. But they may be to the advantage of both parties. They may allow one party to learn more about the advantages that the arrangement may have to hin1. He may need to take steps to learn about its advantages, which he would be unwilling to take unless the other party were already committed. If so, the commitment may benefit the committed party as well, since without it the uncommitted party may be unwilling to contract or to do so on as favorable terms. The straightforward approach would be for a court to ask whether or not a one-sided commitnient is fair. The doctrine of consideration, however, does not allow it to do so.

In some situations where a one-sided commitment is fair, the U.C.C. provides that consideration is not necessary. One is a commitment that is so short-term it is likely to be cost-free. Under the doctrine of consideration, even a short-term, one-sided commitment is invalid. Sometimes courts have found an excuse for not applying the doctrine strictly: for

218. See U.C.C. § 2-209(1) cmt. 2 (1999).

219. See Restatement (SECOND) OF CONTRACTs $\$ 89$ (1979). 
example, the presence of nominal consideration, ${ }^{220}$ or some slight limitation on the freedom of the uncommitted party. ${ }^{221}$ Otherwise, courts have had to refuse to enforce otherwise fair commitments lacking consideration. Under the U.C.C., however, a commitment to buy or sell goods is binding among merchants for up to three months. ${ }^{222}$

A second type of fair one-sided commitment that has become enforceable under the U.C.C. is one to sell or buy whatever quantity of goods the other party may demand or offer. These contracts may be fair because they merely give the uncommitted party the flexibility he needs to run his business efficiently. They may be unfair, however, if they allow the uncommitted party to change the quantity he demands or offers in response to fluctuations in the market price, rather than his own needs. Again, under the doctrine of consideration, such arrangements are invalid, fair or not. Moreover, a clever drafter can use the doctrine of consideration to render an unfair commitment enforceable by providing that some minimum quantity must be sold or bought. To avoid such unfair results, the U.C.C. will enforce such commitments provided that the quantity offered or demanded must be "such actual output or requirements as may occur in good faith."

Other one-sided commitments continue to be governed by the doctrine of consideration and courts must either refuse to enforce a fair contract or find some escape from the doctrine. For example, a one-sided commitment that may be fair is a long-term commercial lease or franchise. The lessee or franchisee may not know at the time he contracts how successful his business will be. It may be greatly to his advantage to be able to terminate his obligations if it fails. But if the lessor or franchisor can terminate as well, he can, in effect, appropriate the location or the business if it is successful. It may be in the interest of both parties to make the commitment one-sided, since otherwise the lessee or franchisee might be unwilling to contract at all or to do so on such favorable terms. Sometimes, courts have managed to uphold such arrangements by seizing on some limitation on a party's power to terminate, such as a requirement that he do so on ten days notice. ${ }^{24}$ Other courts have refused to enforce such

220. See, e.g., Real Estate Co. v. Rudolph, 153 A. 438 (Pa. 1930); Morrison v. Johnson, 181 N.W. 945, 946 (Minn. 1921)(dicta). The second Restatement provides that a written offer can be made irrevocable for nominal consideration if it "proposes an exchange on fair terms within a reasonable time." Restatement (SECOND) OF CONTRACts \$ 87(1) (1979).

221. See, e.g., Gurfein v. Werbelovsky, 118 A. 32 (Conn. 1922) (upholding contract to buy plate glass to be shipped within three months, although the buyer could cancel before shipment, on the grounds that if the seller had shipped immediately, the buyer could not exercise this option).

222. U.C.C. \$ 2-205 (1999). Even such a short term commitment can be struck down as unconscionable if it operates unfairly. See id. $\mathrm{cmt}$. 4 .

223. U.C.C. \$ 2-306(1) (1999).

224. See, e.g., Lindner v. Mid-Continent Petroleum Corp., 252 S.W.2d 631 (Ark. 1952). 
commitments, thereby giving the lessor or franchisor a power to terminate that the parties had agreed he would not have. ${ }^{225}$

A one-sided commitment also may be fair when the value of a transaction to one party depends on studies or tests he has yet to perform, or contractual arrangements with a third party that he has yet to make. Sometimes it is possible to make a contract that is conditional on the outcome of the tests or the consent of the third party to certain terms. Sometimes, however, the question of whether the outcome or the terms are favorable has to be left to the discretion of one of the parties. De facto, at least, he must therefore remain uncommitted. Courts have managed to uphold such arrangements in a variety of ways. In Scott $v$. Moragues Lumber Co., ${ }^{226}$ one party had promised to charter a ship to the other if he decided to purchase it. The court held there to be consideration because the contract was conditional. In Mattei $v$. Hopper, ${ }^{227}$ one party agreed to purchase land for a shopping center if he could obtain satisfactory leases. The court held there to be consideration even though it admitted that the condition of satisfaction was subjective so that the buyer could profess himself dissatisfied even though a reasonable person would not have been. In Wilson $v$. $S p r y,{ }^{228}$ the defendant agreed to hold an offer to sell his land open for fortyfive days so that the prospective buyer could make a thorough examination of it at significant cost to himself. The court found consideration even though, unlike Mattei, there was no commitment to buy if the results were satisfactory.

It is hard to explain Wilson by the bargained-for detriment formula. The prospective buyer did not promise to do the examination, and so he did not limit his legal freedom of action. Perhaps one can explain Scott by saying that the charterer had given up the legal right to refuse to charter the boat if he bought it. Perhaps one can explain Mattei by saying that the prospective buyer had given up his right to pull out if he was really satisfied with the leases even though, if he professed himself dissatisfied, no one would be able to tell. Nevertheless, it would be a mistake to try to shoehorn these cases into the doctrine of consideration because, again, what matters is the fairness of these commitments, and that doctrine cannot distinguish the fair from the unfair. A long-term option can be very unfair. Making it conditional on some trivial decision by the option holder would not make it more fair. The option in Scott was fair because buying a ship is such an important decision that the option holder is unlikely to use it to speculate at the other party's expense. A subjective condition of satisfaction can be

225. See, e.g., Miami Coca-Cola Bottling Co. v. Orange Crush Co., 296 F. 693 (5th Cir. 1924)

(allowing franchisor to escape contract because franchisee had the right to terminate at will).

226. 80 So. 394 (Ala. 1918).

227. 330 P.2d 625 (Cal. 1958).

228. 223 S.W. 564 (Ark. 1920). 
very unfair, although the one in Mattei was not. In Morin Building Products Co. v. Baystone Construction, Inc., ${ }^{229}$ the plaintiff had built a shed for a General Motors plant under a contract that provided G.M.'s "decision in matters relating to artistic effect shall be final." ${ }^{230}$ When G.M. rejected the work on the grounds that the surface of the shed had an uneven appearance when viewed at an acute angle in bright sunlight, Judge Posner, though not a partisan of reviewing the fairness of contracts, came to the rescue by construing the condition of satisfaction as objective rather than subjective. ${ }^{231}$ Finally, a contract in which one party is not committed even conditionally could be very unfair, even though it was not in Wilson, where one party merely wanted a chance to examine the property in good faith. Rather than looking for consideration, courts ought to enforce or not enforce the contract depending on whether it is fair.

A one-sided commitment can also be fair when one party is not certain whether he can perform, or how much his performance will cost. He may not want to commit himself to succeed or to complete the job at a fixed price. The other party may not want to pay him merely for trying, or to pay cost plus. The fair arrangement may be one in which the party who is to perform can quit whenever he wants, but will be paid only if he succeeds. American courts enforce arrangements of this type by calling them "offers of unilateral contract." 232 Supposedly, the party to perform has been made an offer that he can accept only by completing performance.

Here, again, the doctrine emerged when the nineteenth-century treatise writers reworked the action of assumpsit. Before the nineteenth century, it had been said that the consideration for a promise might be something done at the time the promise was made. It also might be something done before the promise was made, provided it was done at the promisor's request. Or, it might be something the promisee was to do in the future, in which case the promisee had to plead that he had actually performed this act. Suppose, however, the consideration was a promise made in the present to perform an act in the future. Would the promisee need to plead that he had performed? English courts traditionally held that he need not because the promise counted as consideration that was given at the time it was made, even though its performance lay in the future. They drew this distinction long before English lawyers considered when the promisee's refusal to perform a promise could be used as a defense by the promisor. ${ }^{233}$ In the nineteenth century, the doctrine of unilateral contract was used to explain this difference in pleading. Some offers, it was said,

\footnotetext{
229. 717 F.2d 413 (7th Cir. 1983).

230. Id. at 414 .

231. See id. at $415-16$.

232. The doctrine has been preserved by the second Restatement although the term "unilateral contract" has been dropped. See Restatement (SECOND) OF CONTRACTs $\$ 45$ (1979).

233. See Simpson, supra note 187 , at $452-65$.
} 
could not be accepted by promising in return but only by doing the act which the promisor requested. ${ }^{234}$ If he offered a reward for the return of property, the offeree could only accept by returning the property. Such an offer was sometimes called one of "unilateral contract," as distinguished from an offer of "bilateral contract," which could be accepted in the ordinary way by making a promise.

As Wormser noted, it seemed to follow that until the offeree had actually done the act requested, an offer of unilateral contract was an unaccepted offer and therefore revocable. ${ }^{235}$ Pollock suggested that the offeree could accept by making "an unequivocal beginning of the performance requested."236 This solution was adopted by the first Restatement, ${ }^{237}$ but it had the odd consequence that the offer became irrevocable if the offeree began to perform, regardless of how little inconvenience this beginning cost him, but not if he had merely made preparation to perform, however substantial his preparations. Consequently, the second Restatement added that the offer could not be revoked if the offeree had relied on the promise in a way that was substantial. ${ }^{238}$

These solutions seem not only over-elaborate but also misconceived if the question is whether the one-sided commitment is fair. If that is so, it should not matter what the "offeree" already has done. What should matter is whether, because of uncertainty about the difficulty or expense of performance, it is fair for one party to be bound even though the other can quit when he likes. A party can make an enforceable bilateral commitment to purchase another party's services even if the party to perform has neither begun performance nor relied upon the proimse. As long as it is fair, a onesided commitment should be treated no differently. ${ }^{239}$

My colleague Melvin Eisenberg has pointed out that the doctrine of consideration was formulated at a time when courts were unwilling to admit that they cared about the fairness of a contract. He has said that, given the general acceptance of the doctrine of unconscionability, which allows a court to examine fairness directly, the doctrine of consideration has become unnecessary except in the limited context of gifts. ${ }^{240} \mathrm{I}$ agree. But I also think, as I have indicated, that we can learn a good deal about which transactions are fair and unfair by the way the courts have applied the doctrine of consideration. We do have to dismantle the doctrine to take

234. See Pollock, supra note 180, at 23-28.

235. See I. Maurice Wormser, The True Conception of Unilateral Contracts, 26 YALE L.J. 136 (1916). He later recanted, "clad in sackcloth." I. Maurice Wormser, Book Review, 3 J. LEG. Educ. 145, I46 (1950).

236. PoLlOCK, supra note 180 , at 26.

237. See RESTATEMENT OF CONTRACTS $\$ 45$ (I932).

238. See Restatement (SECOND) OF CONTRACTS $\$ 87(2)$ (1979).

239. For a fuller discussion, see Gordley, supra note 208, at 603-06.

240. See Melvin Aron Eisenberg, The Principles of Consideration, 67 CoRNELL L. Rev. 640

(1982). 
fairness directly into account. But the attempts that courts have made to use the doctrine to police fairness can sharpen our ideas of when a contract is unfair.

\section{III}

\section{PROPERTY}

It is not surprising that, with a few exceptions, the law of property was not remodeled along the lines of civil law. Property was at the core of older English law. Moreover, wherever civil law has spread, the local rules of property usually have been one of the last areas to be assimilated.

Nevertheless, there has been a great deal of parallel evolution. One distinctive feature of English property law was the so-called common law estates in land: fee simple, fee tail, life estate, and leasehold. Of these, fee tail has been abolished in all but a few American jurisdictions. ${ }^{241}$ Fee simple and life estate look very much like the "ownership" and "usufruct" of civil law. Lease admittedly is different, and I will discuss the difference shortly.

Another traditional difference concerned the role of courts of equity in protecting the "equitable title" of purchasers of land. These rules grew up before there was a recording system. Today, however, in virtually every state, transfer of land is governed by a land transfer act, which varies considerably froin state to state. Moreover, virtually every state has a recording act that prescribes what should happen if the seller conveys the land twice. The old rules governing the equitable title of the prior purchasers apply only in rare cases in which an interest in land cannot be recorded. ${ }^{242}$

Moreover, the acquisition of title by adverse possession resembles civil law prescription, even though it seeins to have developed independently. The problem of "immissioni" in Italy, "Immissionen" in Germany, or "troubles de voisinage" in France looks inuch like that of nuisance in the United States. ${ }^{243}$ The rule that the government must pay just compensation when it takes private property was adopted by the Alnerican Constitution in the eighteenth century. ${ }^{244}$ The problems that rule raises are much like those of similar provisions in continental Europe. In this case, the similarity inay be due to a common source in the natural law school of the seventeenth and eighteenth centuries. In any event, the institutions and rules are much the same.

241. Exceptions are Delaware, Maine, Massachusetts, and Rhode Island. See 2 Richard R. Powell \& Patrick J. Rohan, The Law of Real Property II 196, at 14-16 (rev. ed., 1999).

242. See 14 id. \$ 82.02[3].

243. See James Gordley, Immissionsschutz, Nuisance and Troubles de Voisinage in Comparative and Historical Perspective, 1998 Zeirschrift Für EuropäIsches Privatrecht 13, 15-16.

244. See U.S. Const, amend. V. 
There are, of course, differences. Some say that one difference is fundamental: the common law does not recognize "ownership" in the civil law sense. We will consider this claim, and then turn to some practical differences.

\section{A. Ownership}

Supposedly, the civil law and common law take radically different views of the relationship between ownership and possession. While the common law blurs these concepts, "[c]ontinental law makes a sharp distinction. ${ }^{245}$ The accounts that continental and Anglo-American jurists give of these institutions seem to be polar opposites. Typically, continental jurists say that the owner has the right to possession while the mere possessor does not. Then they try to explam why the law protects someone who is acting without right. In contrast, Anglo-American jurists-particularly the English-say that the common law "never bothered much with the idea of ownership,"246 "never applied the conception of ownership to land,"247 and "never really disentangled [the concept of ownership] from that of possession." ${ }^{248}$ In the common law, supposedly, ownership or title to land is based on the fact of possession or the best right to possession. ${ }^{249}$ Title is therefore relative. The person with possession has title against anyone who does not have a "better right,"

Supposedly, the reason that title is relative is that the common law never protected ownership as such. The medieval actions to recover land protected "seizin," which was something like possession. One who had been seized and was dispossessed would bring an action called "novel disseizin" to get back his land. The heir of someone who had been "seized" of land would bring an action called "mort d'ancestor."252 The closest thing to an action based on ownership was the "writ of right," but even this was an action to protect seizin, since the party who prevailed was the party who could trace his claim to the earliest person to have had seizin. ${ }^{253}$

245. JacoB H. BeEkhuis, Civil Law, in 6 International Encyclopedia of Comparative Law 3, 18 (Frederick H. Lawson ed., forthcoming).

246. Michael Harwood, Modern English land Law 503 (1982).

247. E.H. Burns, Cheshire \& Burn's MOdern LaW of Real Property 25 (14th ed. 1988).

248. R. Megarry \& H.W.R. Wade, The Law of Real Property 104 (5th ed. 1984).

249. See CHESHIRE \& BURNS, supra note 247, at 26; HARWOOD, supra note 246, at 503; MEGARRY \& WADE, supra note 248, at 104.

250. MegarRY \& WADE, supra note 248, at 106; see CheshiRe \& BURNS, supra note 247, at 2627; Kevin Gray, Elements of Land Law 65, 752-53 (1987); K.J. GRay \& P.D. Symes, Real. Property and Real People: Principles of Land Law 49 (1981); Harwood, supra note 246, at 503.

251. See Cheshire \& BuRns, supra note 247, at 852-53; HaRWOOD, supra note 246, at 503; MegarRy \& WADE, supra note 248, at 107.

252. See A.W.B. Simpson, A History OF THE LAND LAW 38 (2d ed. 1986).

253. See id. 
Fifty years ago, two eminent English historians, Sir William Holdsworth and H.D. Hargreaves, argued over whether the rise of the action of ejectment marked a change in "theory" froin the older notion of seizin to a civilian-like notion of ownership and possession. Holdsworth claimed that it did. A plaintiff in ejectment will prevail if, like a plaintiff in a continental real action, he can show he is the true owner or has been in possession for the period necessary to acquire title. He will not prevail if his period of possession was shorter or if the defendant can show title in a third party (the so-called defense of ius tertii). He will also prevail if, like a plaintiff in a continental possessory action, he can show the defendant ousted him from possession. ${ }^{254}$

Hargreaves challenged him, arguing that the concept of seizin still inattered although the English courts were losing sight of it "in a fit of absentmindedness."255 A "yearning for "ownership' infect[ed] the terminology of ejectınent" ever since "a spate of loose language . . . set in with the sentimental liberalism of the [eighteen-]fifties." ${ }^{256}$ Nevertheless, the decisions of these courts could be explained without using the idea of ownership. According to Hargreaves, the reason a plaintiff in ejectinent prevailed if he proved possession for the statutory period was not because he proved his title, but because, under an old English rule, that period established a presumption of "livery of seizm." 257 The reason plaintiff prevailed if he proved he was wrongfully dispossessed was not that he had been wrongfully dispossessed but that he had been disseized. ${ }^{258}$

As I have shown in detail elsewhere, ${ }^{259}$ neither of these opinions is consistent with the English cases through the mid-nineteenth century. Froin the seventeenth century onward, English judges had said that to recover in ejectinent, the plaintiff inust have title. Lord Holt said so in the seventeenth century, ${ }^{260}$ and Lord Mansfield in the eighteenth century. ${ }^{261}$ But it does not follow that Holdsworth is right that the plaintiff had to prove title to recover. It was not clear, in the cases just inentioned, that either party did have title. Moreover, in a subsequent case, even though the plaintiff could not prove he had been in possession for the twenty year period necessary to obtain title, Lord Mansfield allowed the jury to infer possession for the

254. See 7 Sir W.S. Holdsworth, A History OF ENGLISH LAW 57-81 (1926).

255. A.D. Hargreaves, Terminology and Title in Ejectment, 56 L.Q. REv. 376, 398 (1940).

256. Id. at 387.

257. See id. at $382-83$.

258. See id. at 379-80.

259. See James Gordley \& Ugo Mattei, Protecting Possession, 44 AM. J. Comp. L. 293, 319-29 (1996).

260. See Stokes v. Berry, 2 Salk. 421, 91 Eng. Rep. 366 (K.B. 1699) (plaintiff recovers because "the possession of twenty years shall be a good title").

261. See Roe dem. Haldane \& Urry v. Harvey, 4 Burr. 2484, 2487, 98 Eng. Rep. 302, 304 (K.B. 1769) ("plaintiff can not recover, but upon the strength of his own title"). 
requisite twenty years. ${ }^{262}$ In the nineteenth century, courts continued to say that the plaintiff must recover on his title. Nevertheless, they allowed him to recover if he proved forcible dispossession, ${ }^{263}$ and sometimes if he merely proved possession, ${ }^{264}$ on the grounds that he had produced evidence from which title could be inferred. If Hargreaves were right, these courts should not have mentioned title since what mattered was not title but seizin. If Holdsworth were right, they should have insisted that the plaintiff actually prove that he did have title.

Instead, the courts had been reaching results pragmatically with no clear theory. They might have done so indefinitely except that, in the midnineteenth century, some cases finally came before them in which the plaintiff plainly did not have title. They could no longer say that that his prior possession or forcible dispossession was evidence of title. They had to say either that he could not recover or that he need not have title to do so. The court gave the first answer in 1849 in Doe dem. Carter v. Barnard. ${ }^{265}$ Carter took possession and let his son John live on the premises from 1815 to 1834 . His widow remained in possession for thirteen years until she was dispossessed by the defendant, who had no title. The widow lost because, according to the court, prior possession was only prima facie evidence of title. One could see that she did not have title because she had proven the prior possession of her husband. Then, in 1865, in Asher $v$. Whitlock, ${ }^{266}$ the court flip-flopped. Williams had enclosed the waste of a manor in 1842 and again in 1850. He occupied it until he died in 1860 . He left the land to his wife for as long as she remained unmarried, and then to his child Mary Ann. The widow and daughter remained in possession until the daughter died in 1863 . In 1891, the widow remarried. Her daughter's heir then sued the widow and her new husband for the land, and won. Here, as in Carter, it was clear that the plaintiff did not have title. The court held that even if the daughter did not have title, she could not be dispossessed, and that she could pass that right to her daughter. While Asher made it clear that a prior possessor without title could recover his land, that proposition was accepted by civil law systems as well. It hardly committed the common law to a distinct theory about the relationship of ownership and possession. And even if it had, this theory would have emerged only in 1865.

262. See Denn ex dem. Tarzwell v. Barnard, Cowp. 595, 98 Eng. Rep. 1259 (K.B. 1777).

263. See Davison v. Gent, 1 H. \& N. 744, 156 Eng. Rep. 1400 (Ex. 1857); Doe dem. Hughes v. Dyeball, M. \& M. 345, 173 Eng. Rep. 1184 (N.P. 1829); Doe dem. Humphrey v. Martin, Carr \& M. 32, 174 Eng. Rep. 395 (N.P. 1841).

264. Compare Doe dem. Smith \& Payne v. Webber, 1 Ad. \& E. 119, 10 Eng. Rep. 1152 (K.B. 1834) (allowing plaintiff to recover) with Doe dem. Wilkins v. Marquis of Cleveland, 9 B. \& C. 864 , 109 Eng. Rep. 321 (1829) (denying recovery to the plaintiff).

265. 13 Q.B. 945,116 Eng. Rep. 1524 (1849).

266. 1 L.R.-Q.B. 1 (1865). 
Once again, the supposedly ancient common law approach was actually the work of the nineteenth-century treatise writers. Their work cannot be understood apart from continental law, although this time they were not borrowing from the civil lawyers, but were reacting to them. One of the most vigorous debates among nineteenth-century German jurists concerned the reason for protecting a possessor who was not an owner. Savigny and Ihering were the foremost participants. Savigny assumed that only the owner could have a genuine right to possess. ${ }^{27}$ Thus, the question was "how possession, without any regard to its own lawfulness, can be a basis for rights. ${ }^{.268} \mathrm{He}$ answered:

An independent right of the person ... is not violated but the situation of the person is altered to his disadvantage; the unlawfulness, which consists in the use of force against tlris person, can only be eliminated with all of its consequences by the restoration and protection of the factual situation to which the force extended. ${ }^{269}$

This answer is not perfectly clear. It suggests two rather different explanations for the protection of possession, each of wlich had its champions among the German jurists. According to the first explanation, the law protects the peace and order of society against unlawfulness and force. ${ }^{270}$ According to the second explanation, the law protects the victim himself. ${ }^{271}$ The victim has a legally protectable claim against unlawful interference even though he does not have a legally protectable claim to possession.

Ihering criticized both versions of this theory. If the law was concerned with peace and order, it was hard to see why the possessor could recover even if he had not been forcibly dispossessed. ${ }^{272}$ It was also hard to see why the law protected the plaintiff against interference when the defendant had not imterfered with any of his rights. ${ }^{273}$ Ihering's theory was different. By protecting possession, the law gave a more effective

267. See Friedrich Kari von SAvigny, Das Recht des Besitzes 2-3 (6th ed. 1837).

268. Id. at 9.

269. Id. at 41 .

270. See Rudorff, Über den Rechtsgrund der possessorischen Interdicte, 7 ZEITsCHRIFT FÜR GESCHICHTLICHE RECHTSWISSENSCHAFT 90, 110-14 (1831).

271. See Carl Georg Bruns, Das Recht des Besitzes im Mittelalter und in der Gegenivart $\$ 58$, at 491-92 (1848); Eduard Gans, System des röMIschen Civilrechts 211-12 (1827); 2 Georg Friedrich Puchta, Cursus der Institutionen $\$ 224$, at 333 (3d ed. 1851); ANToN RANDA, DER BESITZ MT EINSCHLUSS DER BESITZKLAGEN NACH ÖSTERREICHISCHEM RECHTE $§ 8$, at 284 (3d ed. 1879); 1 Bernhard Windscheid, Lehrbuch Des PandekTenrechts $\$ 148$, at 401 (3d ed. 1873); Carl Georg Bruns, Das heutige römische Recht, in ENCYCLOPÄDIE DER RECHTSWISSENSCHAFT 247, 293 (Franz von Holtzendorff ed., 1870).

272. See RUDOLPH VON IHERING, ÜBER DEN GRUND DES BESITZESSCHUTZES: EINE REVISION DER LEHRE VOM BESIYZ 8 (2d ed. 1869).

273. German jurists had said that the interference was with the will of the victim. Thering argued that the law does not protect the will regardless of what is willed, but rather defines the circumstances in which the will is protected. See id. at 31-34. 
protection to ownership. ${ }^{274}$ The owner would not have to prove his title when dispossessed. ${ }^{275}$ The protection given possessors who were not owners was an "unavoidable consequence," a "price" paid for protecting owners. ${ }^{276}$ Nevertheless, few German jurists agreed with Ihering. Critics pointed out that his theory does not explain why a possessor is protected when he clearly is not the owner, ${ }^{277}$ nor why he is sometimes protected even against the owner. ${ }^{278}$

Both Holmes and Pollock were familiar with this debate. They believed that neither side had won. The problem, they saw, was that it was all but impossible to explain why the law protected possession unless possession itself was a legal right. They concluded that possession and ownership were basically alike. As Holmes said, rights of ownership "are substantially the same as those incident to possession." 279 The difference is that "[t]he owner is allowed to exclude all, and is accountable to no one. The possessor is allowed to exclude all but one, and is accountable to no one but him." ${ }^{280}$ Similarly, according to Pollock, possession conferred "a right in the nature of property which is valid against everyone who cannot show a prior and better right." ${ }^{281}$ Both of them presented their theories as explanations of the common law. Yet nearly all the features of the common law to which they pointed were common to civil law systems as well. ${ }^{282}$ Indeed, Pollock claimed as one of the merits of his theory that it could explain the protection of possession in civil law as well:

$[\mathrm{T}]$ he relations of possession and ownership in Roman and English law, the difficulties arising out of them, and the devices resorted to for obviating or circumventing those difficulties, offer an amount of resemblance even in detail which is much more striking than the superficial and technical differences. We cannot doubt that these

274. See id. at $45-46$.

275. See id. at 47-54.

276. See id. at 55.

277. See RANDA, supra note $271, \S 8$, at 276; 1 HeINRICH DERnBurg, PANDEkTEN $\$ 170$, at 403 (4th ed. 1894).

278. See RANDA, supra note $271, \S 8$, at 276.

279. HoLMES, supra note 197 , at 246.

280. Id.

281. Frederick Pollock \& Robert Samuel Wright, an Essay on Possession in the Common Law 93 (1888). Here he broke with the German jurists, even though elsewhere he gave explanations like theirs for the protection of possession. See id. at 3-4; see also SIR FredERICK Pollock, A First BooK of JURISPRUdence for Students of THE COMMON LAW 174-75 (1896) [hereinafter POLLOCK, JURISPRUDENCE].

282. One feature that Holmes pointed to does differ: civil law gives one action to the owner and another to the possessor, while common law allows both to recover in ejectment. See HoLMES, supra note 197, at 210-11. The reason, historically, is that ejectment originally protected a lessee and became an owner's remedy through a fictitious lease. As we have seen, ejectment did not rest on a theory that identified ownership with possession. 
resemblances depend on the nature of the problems to be solved and not on any accidental connection. ${ }^{283}$

Elsewhere, I have argued that the chief merit of this theory is that it recognizes that, to be worth protecting, possession must be a legal right. ${ }^{284}$ Its chief defect is that it identifies this right with ownership, and so fails to explain why the rights of owners and possessors sometimes differ. For example, the possessor, but not the owner, loses his rights if he voluntarily relinquishes possession without transferring it to another ${ }^{285}$ Whatever its merits, however, we can now see that the identification of ownership and possession is hardly a basic structural feature of the common law. It is a theory of two of the best of the nineteenth-century treatise writers who were responding to a continental debate. According to Pollock, it was as applicable to civil law as to common law.

\section{B. Practical Differences}

While there may be no basic structural difference in the civil law and common law approaches to property law, there are differences in practice. Some of these differences concern the treatment of marital property, but they are beyond the scope of this Essay. The most important remaining differences concern the rules that govern future interests, leases, easements, and covenants. None of them is generally regarded as a triumph of reason.

\section{Future Interests}

The common law recognizes a bewildering variety of so-called "future interests." For example, if $A$ transfers her land to her son for life and then to her son's children when they reach the age of twenty-one, the children would have a future interest called a "contingent remainder." If she transfers her land to a church, and specifies it would go to her niece if it was not used for church purposes, the niece would have a right called an "executory interest." If she transfers the land to her nephew with the proviso that he and his successors will lose it if alcohol is ever served on the premises, she retains a possibility of reversion if the loss is automatic, and a right of reentry if it requires action by the holder of such a right.

283. Pollock, JURISPRUdENCE, supra note 281 , at 179.

284. See Gordley, supra note 259 , at 328.

285. That proposition has some support in British law. See Agency Co. v. Short, 13 App. Cas. 793, 799 (1888) (finding that "[t]he possession of the intruder, ineffectual for the purpose of transferring title, ceases upon its abandonment to be effectual for any purpose"); Allen v. Roughly, 94 C.L.R. 98 (1955) (Austl.). It was settled early on in the United States. See Smith ex dem. Teller v. Lorillard, 10 Johns. 338 (N.Y. Sup. Ct. 1813) (finding that the prior possessor recovered because he did not leave voluntarily, but was expelled by British troops in 1776); Sabariego v. Maverick, 124 U.S. 261 (1887) (holding that prior possessor who left land voluntarily cannot prevail against current possessor). 
While leases, covenants and easements are tools of land use planning, future interests normally are not. For example, the owner of a shopping center will lease space to the Gap clothing store, not transfer title for as long as the space is used as a clothing store. To the extent that they are not simply a means to avoid paying taxes, future interests are most commonly a tool for inter-generational family planning. They permit people to say how and by whom their wealth will be used after they die. A limit to their freedom to do so is set by the rule against perpetuities. It provides that, at the moment of their creation, contingent remainders and executory interests must vest within a life-in-being plus twenty-one years.

To belabor the obvious, it is hard to see why we should use this complicated set of rules to determine to what extent a dead person can control the disposition of wealth. The rules do not even represent the views on that issue of the judges who made them. Rather, they are the outcome of a centuries-long tug-of-war between judges and ever more ingenious drafters. In any event, it is hard to see why we should now follow the views of long-dead judges who lived in a society with different ideas about the usefulness and wisdom of perpetuating familial control.

Even if we wished to defer to those views today, to limit control by the rule against perpetuities is as odd a limit as one can imagine. The rule draws peculiar distinctions between the way in which contingent remainders vest and the way in which executory interests do. Possibilities of reverter and rights of reentry are not subject to the rule at all, and, in principle, can go on forever. ${ }^{286}$ To the extent these interests are alienable, as they often are, the constraints of the rule against perpetuities can be evaded by a careful drafter. ${ }^{287}$ If the drafter is not careful, however, the least misstep can destroy the interest his client wished to create. Every first-year law student learns to avoid obvious pitfalls. They learn, for example, to consider the obvious possibilities that, in legal contemplation, octogenarians may have children, and, indeed, by spouses that are still unborn. Thus, it is permissible to leave property to one's children's children when they turn twenty-one, but not to those of one's sister if she is still alive, nor to the children of one's brother's widow when they turn twenty-one. But the less obvious pitfalls are so hard to avoid that, as Jesse Dukeminier has observed, even highly respected lawyers can fall into them. ${ }^{288}$ Indeed, in California it has been held not to constitute malpractice to do so. ${ }^{289}$

286. See Michael A. Heller, The Boundaries of Private Property, 108 YALE L.J. 1163, 1181 (1999).

287. See id.

288. Jesse Dukeminier, A Modern Guide to Perpetuities, 74 CALIF. L. Rev. 1867, 1912 (1986).

289. See Lucas v. Hamm, 364 P.2d 685 (Cal. 1961). 


\section{Leases}

While the common law leasehold roughly corresponds to the civil law lease, there is a fundamental difference. In common law, the lease was conceived not as an on-going contract, as it is in civil law, but as the conveyance of an interest in land. The tenant had "bought" a certain physical space for a certain period of time. The landlord had no duties to keep it in repair unless he assumed them expressly. If he did, the tenant could sue for violation of these duties, but could not give back the premises and move out. If the tenant moved out in violation of the lease, the landlord had no duty, and initially, no right, to find a new tenant. If the tenant did not pay the rent, the landlord could sue for it, payment by paynient, but he could not repossess the premises.

These rules have been breaking down. For a long time, courts escaped them by a series of fictions. For example, if the condition of the premises became bad enough, courts have held that the tenant can leave because the landlord has constructively evicted him. ${ }^{290}$ Now, if a tenant leaves in violation of the lease, the landlord can find a new tenant, either because he is deenied to be accepting the tenant's offer to terminate the lease, or because he is deemed to be the tenant's agent in finding a new tenant. ${ }^{291}$ More recently, the old rules have been attacked, without fiction, by treating the lease as a contract, and applying contract doctrines such as substantial breach, ${ }^{292}$ inipossibility and frustration of purpose, ${ }^{293}$ the duty to mitigate damages, ${ }^{294}$ warranties of habitability, ${ }^{295}$ and unconscionability. ${ }^{296}$

The advantage of these doctrines is that a lease, like many other contracts, is an ongoing consensual relationship between the two parties. They were developed to deal with the problems that can arise in an ongoing relationship: circumstances change, a party defaults, or one party treats the other unfairly. Courts are recognizing that a lease should not be treated as a conveyance of property which, in principle, leaves a transferor without ongoing obligations to the transferee. But if that is so, then it seenis that we should follow the law of contract whenever it conflicts with some remnant of the old common law approach.

290. See, e.g., Reste Realty Corp. v. Cooper, 251 A.2d 268 (N.J. 1969).

291. See, e.g., Novak v. Fontaine Furniture Co., 146 A. 525 (N.H. 1929); Ralph v. Deiley, 141 A. 640 ( $\mathrm{Pa}$. 1928).

292. See, e.g., Lemle v. Breeden, 462 P.2d 470 (Haw. 1969).

293. See, e.g., Albert M. Greenfield \& Co., Inc. v. Kolea, 380 A.2d 758 (Pa. 1976).

294. See, e.g., Sommer v. Kridel, 378 A.2d 767 (N.J. 1977).

295. See, e.g., Hilder v. St. Peter, 478 A.2d 202 (Vt. 1984); Foisey v. Wyman, 515 P.2d 160 (Wash. 1973).

296. See Unif. Residential Landlord and Tenant Act $\S 1.303$ (1972), 7B U.L.A. 444 (1985). 


\section{Easements and Covenants}

Easements, covenants and equitable servitudes are restrictions voluntarily imposed on the use of a landowner's property that are intended to bind future owners of the same property. Their validity is supposed to depend on a series of technical rules developed by English courts and formalized in the nineteenth century. According to these rules, if a landowner gives another party the right to do something on his land, or if he agrees not to do certain things there himself, the restriction is an easement, and common law courts will enforce it. If the owner agrees not to do certain other things, or if he agrees to do soinething himself, the restriction is a covenant, and common law courts will enforce it only if it satisfies certain technical requirements called "touch and concern" and "privity." If these requirements are not satisfied, the covenant still may be enforceable in courts of equity, in which case it is termed an "equitable servitude."

It is bizarre, however, to set up elaborate technical requirements that one type of interest inust meet only to escape thein through the creation of another type of interest. Modern American scholars have been less interested in these inherited distinctions and more interested in the purposes served by such voluntary restrictions on land use. Their approach has culminated in the tentative drafts of the Third Restatement of Property. Instead of distinguishing among easements, covenants, and equitable servitudes, the drafters of the Restatement use a single category, "servitudes." ${ }^{297}$ Validity is determined, not by the traditional requirements of privity and touch and concern, but by "the modern approach of addressing directly the probleins created by servitudes that violate constitutional, statutory or public policy norms." ${ }^{298}$ If this approach triumphs, as seems likely, the American law of servitudes would not become identical to the civil law, since it would permit much that the civil law forbids-for example, the creation of affirmative duties. Nevertheless, this approach would free the law of servitudes from the grip of the traditional common law.

\section{Rethinking the Law of Property}

It would not be fair to say that every difference between the AngloAmerican law and civil law of property reflects poorly on the AngloAmerican law. There is one creation of the courts of equity that is useful indeed and has no civil law parallel: the trust. One person, the settlor, can

297. Restatement (Third) of Property (Servitudes), Tentative Draft No. 1 (1989), Introduction xxiii-xxvi.

298. Restatement (Third) of Property (Servitudes), Tentative Draft No. 2 (1991), Introduction, $x v ; \S 3.2$ ("Touch and Concern Doctrine Superceded"); Restatement (Third) of Property (Servitudes), Tentative Draft No. 1 (April 5, 1989), \& 2.4 ("No Horizontal Privity Required"). 
transfer assets to another, the "trustee," who is then obligated to use them for the benefit of someone else, "the trust beneficiary." The trust is unlike a civil law mandate. In a mandate, one person instructs another to perform an action on his behalf. In a trust, the settlor can no longer exercise control over the trustee. A trust is unlike a civil law contract in favor of a third party because the third party has a real right to the assets in the trust, not merely a contract claim against the trustee. In fact, the trust is so useful that civil law countries are considering adopting it. ${ }^{299}$ I can see only advantages, however, in leaving behind the traditional law of future interests, leases, and easements and covenants.

\section{IV \\ RESTITUTION}

The common law of restitution developed in a different way than tort, contract and property. Traditionally, there was no law of restitution as such, but rather a hodgepodge of remedies with one characteristic in common: the plaintiff's recovery was not limited by the loss that he had actually suffered. One of these remedies was for so-called quasi-contracts. Certain people who had received a benefit from the plaintiff were treated as though they had done so under a contract. In 1888, Ames suggested that the reason was that they had been unjustly enriched. ${ }^{300}$ This explanation was adopted by the first treatises on quasi-contracts: those of Keener in $1893^{301}$ and Woodward in $1913 .{ }^{302}$ In 1937, the American Law Institute published a Restatement of the Law of Restitution with the subtitle Quasi Contracts and Constructive Trusts. In principle, relief was given when one person had been "unjustly enriched at the expense of another." 303

Here again, they were following in the steps of the continental jurists. Roman law recogmized particular cases of what we now call unjust enrichment. ${ }^{304}$ The Digest of Justinian stated the general principle that no one should be enriched at another's expense. ${ }^{305}$ This principle was refined and developed by the late scholastics in the sixteenth century and by the natural lawyers in the seventeenth and eighteenth centuries ${ }^{306}$ Indeed, Lord

299. See, e.g., Convention on the Law Applicable to Trusts and on Their Recognition (International Convention of La Haye, July 1, 1985) Gr. Brit. T.S. 14 (1992), 23 I.L.M. 1388 (parties include Australia, Canada, U.K., Italy; signatories include France, Luxembourg, Netherlands).

300. See J.B. Ames, The History of Assumpsit, 2 HARv. L. REV. 53, 64 (1888).

301. See William A. Keener, A Treatise on the Law of Quasi-Contracts 16 (1893).

302. See Frederic Campbell Woodward, The Law of Quasi Contracts $\$ \$ 8-9$, at 9-10

(1913).

303. RESTATEMENT OF RESTITUTION $\$ 1$ (1937).

304. See ZMMmermanN, supra note 12 , at 838-57.

305. DiG. 12.6.14; Dig. 50.17.206.

306. See Grotius, supra note 21, at II.x.5; Lessius, supra note 19, at bk. 2, ch. 14, dub. 1, no. 3; Molina, supra note 19, at disp. 718, no. 2; PuFENDORF, supra note 21, at IV.xiii.9. See generally Robert Feenstra, L'influence de la scolastique espagnole sur Grotius en droit privé: quelques 
Mansfield had drawn on this tradition in the famous case of Moses $v$. MacFerlan, ${ }^{307}$ when he said that one recovered in assumpsit "quasi ex contractu, as the Roman law expresses it" on grounds of "natural justice and equity." 308

If the treatise writers had dealt with restitution in the same way they did with tort and contract, they would have rebuilt the common law on a civil law ground-plan. As with the Restatements of Tort and Contract, the Restatement of Restitution would have put the capstone on the treatise writers' work in this field. Perhaps because the English law was such a hodgepodge, they preserved more and systematized less. As John Dawson has said, "any suggestion that the continuities [the courts] were creating added up to a 'law' of restitution would have been met for decades with disbelief." ${ }^{09}$ Despite its claim to be based on general principles, the Restatement, as Dawson observed, merely "patched the parts together and gave the subject a name." ${ }^{\text {110 }}$ The first comprehensive American treatise on restitution, written by Palmer, was published only in 1978. ${ }^{311}$ The project of a second Restatement was scrapped after only two partial tentative drafts were produced ${ }^{312}$ although now a "third Restatement" is in progress. In England, in 1978, Lord Diplock insisted that "there is no general doctrine of unjust enrichment recognised in English law." ${ }^{133}$ Nevertheless, in that year, a treatise of the English law of restitution was published by Goff and Jones, ${ }^{314}$ which was followed in 1985 by the still more systematic one of Birks. ${ }^{315}$ In 1991, the English courts finally acknowledged that there is a law of restitution. ${ }^{316}$

Thus, while a sustained effort to systematize the law of tort and contract began in the nineteenth century, an effort to do so with the law of restitution has begun only in the last few decades. It is too early to tell what it will produce. I believe, however, that we are courting the same dangers as the systematizers of tort and contract. Like them, we are trying to rationalize the law by drawing on a principle developed by continental lawyers: that no one should be enriched at another's expense. If the field is to have any unity, it niust be based on that principle. The danger is to imagine

\footnotetext{
expériences dans des questions de fond et de forme, concernant notamment les doctrines de l'erreur et de l'enrichissement sans cause, in FATA IURIS RomanI: ETUdes D'HistoIre Du DRolt 338 (1974).

307. 2 Burr. 1005, 97 Eng. Rep. 676 (K.B. 1760).

308. 2 Burr. at 1008,97 Eng. Rep. at 678.

309. John P. Dawson, Restitution Without Enrichment, 61 B.U. L. Rev. 563, 564 (1981).

310. Id. at 564-65.

311. See George E. Palmer, The Law of Restitution (1978).

312. Restatement (SECOND) of Restitution (Tentative Draft No. 1, 1983); Restatement

(SECOND) OF Restitution (Tentative Draft No. 2, 1984).

313. Orakpo v. Manson Investments Ltd., [19781 App. Cas. 95, 104 (H.L.).

314. LoRd Goff of Chieveley \& Gareth Jones, The LaW OF Restitution (1978).

315. Peter Birks, An Introduction to the Law of Restitution (1985).

316. Lipkin Gorman v. Karpnale Ltd. [1991] 2 App. Cas. 548 (H.L.).
} 
that, without major surgery, heterogeneous cases that were decided under a variety of traditional rubrics and without this principle clearly in sight can be reconciled with it. If we simply recognize that many of them cannot be reconciled, the long-term damage will be small. Gradually, courts and scholars can decide which outcomes are truly irrational, and can weed these out. The danger is that, as in the cases of contract and tort, they will not approach the question with an open mind. They will think their job is to show how the principle explains as many of the decided cases as possible. They will then manipulate the case law to fit the principle, or formulate an unconvincing principle to fit the case law, or both, and then present the end result as the common law.

One can see such a tendency in some of the best scholarly work being done on the law of restitution. An illustration is the treatment given restitution for wrongs. Traditionally, if the defendant had infringed on the plaintiff's rights, the plaintiff sometimes could recover more than his own loss. If the defendant took his personal property, or dug minerals or cut timber from his land, the plaintiff could sue in conversion and recover the reasonable value of whatever the defendant had taken, even if that were more than the loss the plaintiff had suffered ${ }^{317}$ It did not matter whether the defendant had intended to do wrong, had been negligent, or had acted innocently and carefully, although if he intended to do wrong, some courts refused to let him deduct from his dainages any labor or expense he had incurred, for exainple, digging the minerals or selling the timber. ${ }^{318}$ If the defendant sold whatever he had taken (and eventually, in most jurisdictions, if he had merely used it himself ${ }^{319}$ ), the plaintiff could "waive" the tort of conversion and sue in assumpsit for the price the defendant received (or the value of the use) ${ }^{320} \mathrm{He}$ could not do so if the defendant committed a trespass to land. ${ }^{321}$ If the defendant entered into possession, however, the plaintiff could recover "mesne profits" in trespass, which were equal to the reasonable value of the use the defendant had made of the land ${ }^{322} \mathrm{He}$ could not do so if the defendant had trespassed and made a use of the land that was less extensive and so did not count as an entry into possession. In equity, the plaintiff could recover for another type of wrong: a violation of fiduciary duty. The fiduciary who accepted a bribe or took an opportunity for himself that he should have offered to his principal had to disgorge his profit. ${ }^{323}$

317. 1 PALMER, supra note $311 \S 2.3$, at $60 \mathrm{n} .1 ; \S 2.5$, at 73 .

318. Maye v. Tappan, 23 Cal. 306 (1863); accord, Restatement of Restitution $\S 151$, illus. 5

(1937).

319. Dawson, supra note 309, at 610; PALMER, supra note 311, § 2.2, at 54.

320. 1 PALMER, supra note $311, \S 2.2$, at 53-54.

321. Id. § 2.5 at 74; RESTATEMENT OF RESTITUTION § 129 (1937).

322. 1 PALMER, supra note $311, \S 2.5$, at 77 .

323. Id. § 2.11, at 141-57. 
It is not easy to reconcile all these results with the principle that no one should be enriched at another's expense. As Palmer has noted, it is anomalous to deny recovery when the defendant was enriched by a trespass to land that did not amount to taking possession. ${ }^{324}$ It would seem anomalous that the plaintiff sometimes can recover when the defendant has not been enriched at all. Yet a defendant who converted the plaintiff's goods, innocently or not, may be liable for the reasonable value of the goods at the time they were taken, even if they were sold for less. ${ }^{325} \mathrm{~A}$ person who bought the plaintiff's goods from a third party, innocently or not, and then resold them for the same price is liable for that price. A defendant who dug the plaintiff's minerals or cut his timber, knowing that he was doing wrong, is liable for their value without recovery of his expenses. Finally, it would seem anomalous that sometimes the plaintiff can recover when the enrichment did not take place at his expense. The fiduciary must disgorge his profit even if the plaintiff would not have received the bribe even in the form of a better price or would not have taken the opportunity for himself. ${ }^{326}$

I do not deny that some of these results may be justified by concerns that have little to do with the law of restitution. For example, if the plaintiff's personal property is stolen, it may make sense to allow him to recover from the bona fide purchaser who had resold it. As a matter of property law, he could reclaim the physical item that was stolen from the bona fide purchaser. The reason has nothing to do with unjust enrichment. It concerns the buyer's ability to protect himself by dealing with someone who is reputable or at least amenable to a lawsuit. Perhaps for the same reason, the owner should be able to demand the price.

Again, it may make sense sometimes to impose a penalty on an intentional wrongdoer in order to deter misconduct. Sometimes, one might want to impose a penalty whether or not the wrongdoer had been enriched, or whether or not he had been enriched at the plaintiff's expense. Moreover, one might sometimes want the penalty to exceed the amount by which the wrongdoer has been enriched. But then the concern is deterring misconduct, which is quite different from redressing unjust enrichment. The true analogy would be to an award of punitive damages. As with punitive damages, it inakes sense to impose the penalty on one who knew he was doing wrong, and therefore could have been deterred. It does not make sense to impose such a penalty on an innocent converter. The penalty should reflect the gravity of the wrong done. Therefore, the seriousness of a breach of a fiduciary duty should be taken into account before confiscating profits. Also, the amount of the penalty should reflect the need to deter. If the

324. Id. $\$ 2.5$, at 76 .

325. Felder v. Reeth, 34 F.2d 744 (9th Cir. 1929); 1 PALMER, supra note $311, \S 2.2$, at 56.

326. I PALMER, supra note $311, \S 2.11$, at 144-46. 
penalty exceeded the wrongdoer's enrichment, it should be because of that need. One should not have an automatic rule that the willful converter cannot deduct his expenses.

My difficulty with some of the best writing on the law of restitution is not that the authors disagree with me on these points. It is that they seem to assume too easily that results like those I have described must fit within the law of restitution. They shape their theories of restitution to fit these results without first asking whether the results are reasonable at all, and if they are, whether it is because of concerns that are foreign to the law of restitution.

For example, Dawson argued that it usually should not matter whether the defendant has been enriched in the sense that the value of what he owns has increased. ${ }^{327}$ In support, he cites the cases in which a converter is held liable for the market value of property even if he sells it for less. ${ }^{328}$ But these cases are evidence of what constitutes unjust enrichment only if they really are concerned with unjust enrichment. One cannot assume that they are. They follow a rule that was laid down when judges thought in terms of conversion, not in terms of unjust enrichment.

Birks divides the law of restitution into two large categories: restitution "by subtraction" from the plaintiff's wealth and restitution "for wrongs." 329 In discussing the latter category, he explains that the defendant can be liable for a "wrong" even if he was not enriched at the plaintiff's expense. ${ }^{330}$ For exanple, the British government once recovered the bribes paid to a sergeant to guide smugglers through army road posts in Cairo. ${ }^{331}$ Indeed, a defendant can be liable for a "wrong" even if he acted in good faith and was not enriched at the plaintiff's expense: ${ }^{332}$ For example, a solicitor who acted in good faith but committed a technical breach of his fiduciary duty to a trust had to disgorge the profit he made on shares he acquired, even though it was clear that the trust itself would never have acquired these shares. ${ }^{33}$ According to Birks, "[t] he reason why these two cases are unequivocal examples of restitution for wrongs is that it is beyond argument that the only connexion between the plaintiff and the defendant's profit was a wrong." "334 As further examples, he cites "instances of conversion by sale" where "it is not certain that [the victim] would lave received that or any price; and the wrongdoer having perhaps paid another

327. For a criticism of this view, see James Gordley, Restitution Without Enrichment? Change of Position and Wegfall der Bereicherung, in The LAW OF UNJustified ENRICHMENT (D. Johnston \& R. Zimmermann eds., forthcoming Cambridge University Press).

328. See Dawson, supra note 309, at 610-11.

329. B1RKs, supra note 315 , at 319.

330. Id.

331. Reading v. A.-G. [1951] App. Cas. 507 (H.L.).

332. BIRKs, supra note 315 , at 320 .

333. Boardman v. Phipps, [1967] 2 App. Cas. 46 (H.L.).

334. BIRKs, supra note 315 , at 320. 
for the car may not seem to have been enriched at all. ${ }^{1335}$ Having turned these anomalies into a category of the law of restitution, he suggests that a thug must pay the plaintiff money that he took in return for beating him up. ${ }^{336} \mathrm{He}$ supports that claim by citing cases of punitive damages. ${ }^{337}$ This procedure seems to me to be backward. The first question should be whether the cases which supposedly involve the law of restitution can be accounted for on the same principles as awards of punitive damages. If so, they may have nothing to do with the law of restitution. If not, they may be anomalies which we should escape.

Most recently, Weinrib presented a theory of damages in restitution based on commutative justice. Up to a certain point, his theory works rather well: if "the opportunity to gain rightfully belonged to the plaimtiff, ${ }^{, 338}$ the defendant who appropriated it must give it back simply because he has taken something that belongs to the plaintiff. That is why the plaintiff can recover more than he himself has lost. In my view, Weinrib's theory gets into trouble when he tries to explain why the fact that the defendant acted willfully should affect the plaintiff's recovery. He argues that the defendant who knowingly mines the plaintiff's gold cannot recover his expenses because his claim is "normatively incoherent": 339 it "asserts what the severance as willful trespass denied, that the defendant regards the interaction with the plaintiff as governed by the parties' rights." ${ }^{340}$ If the defendant profits by violating his fiduciary duty to the plaintiff, the plaintiff should recover, even if he would not have made the profit, because it can be regarded as "what the fiduciary has, as it were, sold out the duty for. ${ }^{341}$ If the defendant is a thug paid to beat up the plaintiff - citing Birks for the example - he has a right to the thug's fee because the defendant "treated the plaintiff's bodily integrity as an item that [he] was in effect selling for a price." ${ }^{342}$ In such cases, Weinrib claims, "the significance of the wrongfulness is not merely that it produces the gain, but that it survives into the gain and informs it." ${ }^{1343}$ Elsewhere, I have criticized Weinrib's theory, in part, because I cannot understand what it means for wrongfulness to survive into a gain and inform it, and in part because it seems to me merely a metaphor to say that the defendant has treated the plaintiff's trust or bodily integrity as though it were something

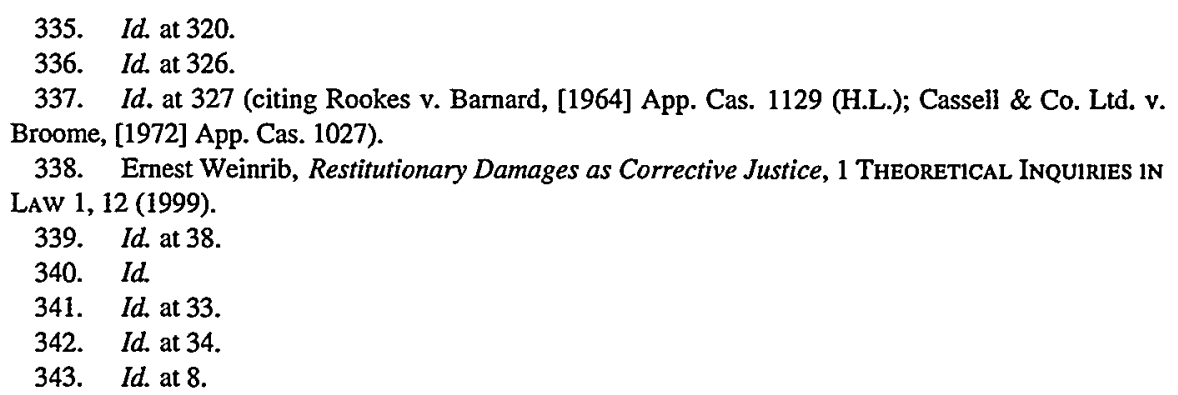


to be sold. ${ }^{344}$ Here, I will merely note that Weinrib only needs to stretch his theory so far to explain these cases if the cases are, indeed, instances of unjust enrichment. Again, there is no reason to assume that they are. They were decided in accordance with rules laid down before judges thought that they were giving relief for unjust enrichment.

\section{CONCLUSION}

Even in the United States, the common law has become part of our national mythology. It was Sir Edward Coke who told King James that though a king was not under man, he was under God and the law. ${ }^{345}$ It was common law judges who gave King Charles trouble over ship money collected without a vote by Parliament. ${ }^{346}$ Had they not done so, perhaps the Massachusetts Bay colonists would not have given King George trouble about taxation without representation. But it was also the common law judges who left us a private law that even the nineteenth-century treatise writers could not fully rationalize. The relics of the old English common law cannot be defended either rationally or pragmatically. Their function and often their significauce today is so different that they cannot be defended by an appeal to tradition. We can root them out without worrying about a return of the Stuart dynasty.

If we do so, our law will be much like that of civil law countries. René David once classified legal systems into three main families: common law, civil law, and socialist law ${ }^{347}$ This classification never worked very well. The law codes of Lenin and Stalin were based on those of France and Germany. Beginning with Blackstone, as we have seen, large portions of the common law were rebuilt on a civil law ground-plan. In any event, presumably recent events in eastern Europe have reduced the number of families to two. If we break our last ties with the traditional English common law, the number will be reduced to one.

I have argued that we must do so simply in the interest of coherent thinking and sensible outcomes. If we do, however, we may also discover that coherence and good sense have little to do with national boundaries. We will have moved toward a world in which jurists everywhere recognize that the fundamental problems are the same, and can talk about them in the same vocabulary.

344. See James Gordley, The Purpose of Awarding Restitutionary Damages: A Reply to Professor Weinrib, 1 THEORETICAL INQUIRIES IN LAW 39, 52-55 (2000).

345. By his own account. Sir Rafe Boswell, who was there, said he fell on all fours and begged for mercy, though he certainly displayed great courage on other occasions. CATHERINE DRINKER BOWEN, The Lion Under the Throne: The Life AND Times of Sir Edward CoKe (1552-1634) 305 (1957).

346. Although the majority sided with the king. C.V. Wedgwoon, THE KIng's PEACE 167-68 (1956).

347. See RenÉ David, Les Grands Systèmes de Droit Contemporains (8th ed. 1982). 
